\title{
7. Sınıf Öğrencilerinin Rasyonel Sayılar Konusunda Kullandıkları Sayı Duyusu Stratejilerinin İncelenmesi
}

\section{Investigation of Number Sense Strategies of 7th Grade Students on Rational Numbers}

\author{
Kürşat YENILMEZ*
}

\author{
Şafak YILDIZ ${ }^{* *}$
}

Received: 6 November 2017
Accepted: 29 March 2018

\begin{abstract}
The purpose of this study is to examine the sense of number strategies used by the 7th grade students on rational numbers. The study was attended by 38 seventh grade students, 19 female and 19 male students studying in a state school in Manisa. The achievement test developed by the researchers was applied to the students. Qualitative method was used in analysis of data. As a result of the research, it was seen that female students were more successful than male students in using number sense. It was determined that students who have received preschool education were more successful than those who have not. It has been seen that the students are more successful in the component of number effect of numbers on transactions. It has been found that students use very few number sense components that they use generally rule-based methods to solve questions. It is seen that students do not prefer to use ways such as interpreting and predicting numbers, reasoning and practical thinking. When students are asked to place numbers on the number line according to the given length, when they are asked to order, the students do not take into account the given length of the numbers and they do not take into account the signs of the numbers when they ask for the numbers. Some students think that the multiplication process always increases the number, while the division process always reduces the number. It is seen that some students can not estimate the approximate value of a consecutive number or the closeness of fractions to a fraction or a whole.
\end{abstract}

Keywords: number sense, rational numbers, flexible calculation.

ÖZ: Bu çalışmanın amacı 7. sınıf öğrencilerinin rasyonel sayılar konusunda kullandıkları sayı duyusu stratejilerini incelemektir. Çalışmaya Manisa'da bir devlet okulunda eğitim gören 19 kız,19 erkek öğrenci olmak üzere 38 yedinci sınıf öğrencisi katılmıştır. Öğrencilere araştırmacılar tarafından geliştirilen başarı testi uygulanmıştır. Verilerin analizinde nitel yöntem kullanılmıştır. Araştırma sonucunda sayı duyusu kullanımında kız öğrencilerin erkek öğrencilerden daha başarılı oldukları görülmüştür. Sayı duyusu kullanımında okul öncesi eğitim alan öğrencilerin almayanlardan daha başarılı oldukları belirlenmiştir. Öğrencilerin sayı duyusu bileşenlerinden "işlemlerin sayılar üzerindeki etkisi” bileşeninde daha başarılı oldukları görülmüştür. Öğrencilerin soruların çözümünde genellikle kural temelli yöntemler kullandıkları sayı duyusu bileşenlerini çok az kullandıkları tespit edilmiştir. Öğrencilerin sayıları ve işlemleri yorumlayıp tahmin etme, muhakeme yapma ve pratik düşünme gibi yolları kullanmayı tercih etmedikleri görülmüştür. Öğrencilerin genel olarak rasyonel sayılarda çarpma işlemi yaparken payda eşitledikleri, verilen uzunluğa göre sayıları sayı doğrusuna yerleştirmeleri istendiğinde verilen uzunluğu dikkate almadıkları, verilen sayıları sıralamaları istendiğinde sayıların işaretlerini dikkate almadıkları tespit edilmiştir. Bazı öğrencilerin çarpma işleminin her zaman sayıyı büyüttüğünü, bölme işleminin ise her zaman sayıyı küçülttüğünü düşündükleri görülmektedir. Bazı öğrencilerin bir kesrin yaklaşık değerini ya da kesirlerin yarıma veya tama ne kadar yakın olduklarını tahmin edemedikleri görülmektedir.

Anahtar kelimeler: sayı duyusu, rasyonel sayılar, esnek hesaplama.

\footnotetext{
*Prof. Dr., Eskişehir Osmangazi University, Eskişehir, Turkey, kyenilmez@ogu.edu.tr

${ }^{* *}$ Corresponding Author: Mathematics Teacher, Ministry of National Education, Manisa, Turkey, safakyildiz@windowslive.com
}

\section{Citation Information}

Yenilmez, K., \& Yıldız, Ş. (2018). 7. sınıf öğrencilerinin rasyonel sayılar konusunda kullandıkları sayı duyusu stratejilerinin incelenmesi. Kuramsal Eğitimbilim Dergisi [Journal of Theoretical Educational Science], 11(3), 457485. 


\section{Giriş}

Günlük hayatta ihtiyaç duyduğumuz becerilerden biri de anlık tahminde bulunup bir yargıya varmaktır. Birinin boyunun uzunluğu tahmin edilirken genelde bir referans noktası alınarak tahminde bulunmaya çalışılır. Veya bir ürünün değeri hesaplanırken onunla eş değerdeki bir ürüne bakılarak değer biçilmeye çalış1lır. Günlük hayatta bireylerden "bir bardaktaki suyun ne kadarı doludur?" sorusuna "yarısı dolu, yarısından biraz fazla, dörtte üçünden biraz az" gibi tahmini cevaplar verebilmeleri beklenmektedir.

İyi bir tahmin yapabilmek için sayıları tanımak ve ne anlama geldiklerini bilmek gerekmektedir. Bir üzüm üreticisinin 98 çuval üzümü olduğunu varsayalım. Her bir üzüm çuvalının ortalama $56 \mathrm{~kg}$ olduğunu varsayalım. Bu durumda çiftçinin sayı duyusunu kullanarak 98 çuvalı 100 çuvala yuvarlaması ve "56 x 100 yaklaşı 5600 kg kuru üzüm üretmişim” demesi beklenir.

Zihinden hesaplama ve tahmin yapabilme sayı duyusunun önemli bileşenleri arasında yer almaktadır. Öğrencilerin sayı duyusunu kullanmalarının yolu ilkokuldan itibaren sayı duyusu stratejilerini öğrenmeleriyle gerçekleşebilir. Matematik dersi öğretim programı kapsamında matematik eğitiminin genel amaçları içerisinde "tahmin etme ve zihinden işlem yapma becerilerinin etkin bir şekilde kullanılabilmesi ve kavramların farklı temsil biçimleri ile ifade edilebilmesi" gibi sayı duyusunu geliştirecek becerilere yer verilmiştir. Yine öğretim programında "tahmin etme ve tahmini sonuçla karşılaştırma, zihinden işlem yapma ve benzeri kazanımlarla öğrencilerin fikirlerini harekete dönüştürme yeteneğini geliştirmenin” (MEB, 2017) amaçlandığı ifade edilmektedir. NCTM (1989) sayı duyusuna sahip çocukların özelliklerini şu şekilde ifade etmiştir: "(1) sayıların anlamlarını çok iyi bir şekilde anlar, (2) sayılar arasında çoklu ilişkiler geliştirir, (3) sayıların göreceli büyüklüklerini fark eder, (4) işlemlerin sayılar üzerindeki etkilerini anlar, (5) çevresindeki nesnelerin ölçümleri için kıyaslama (referans) noktası geliştirir” (aktaran, Yapıcı, 2013, s. 8).

Sayı duyusu üzerine alan yazında farklı çalışmalar yapılmıştır. Bu çalışmalarda sayı duyusunun tanımı ve bileşenlerine yer verilmiştir. Greeno’a (1991) göre sayı duyusu, zihinsel esnek hesaplama, hesaplamalarda sayısal tahminde bulunma ve niceliksel yargılarda bulunma gibi zor olan önemli yetenekleri ifade eder ve sayı duyusunun üç bileşeni bulunmaktadır. Bunlar:

1) Esnek sayısal hesaplama: Bu sayı duyusu bileşeni zihinsel çarpmada sayıları yeniden gruplandırmak için denkliklerin tanınmasını içerir. Hope \& Sherrill (1987) tarafından lise öğrencilerinin zihinsel çarpma stratejilerinin incelendiği çalışma sonucunda bazı öğrencilerin 25 x 48 problemini çözmek için problemi (100/4) x 48 daha sonra 100 x (48/4) daha sonra 100x12'ye dönüştürdükleri ve cevabı 1200 olarak buldukları ifade edilmektedir (aktaran, Greeno, 1991, s. 171).

2) Sayısal Tahmin: Sayı hissi için kanıt olarak alınan başka bir gösterge çeşidi ise hesaplama bağlamında yaklaşık sayısal değerlerin fark edilmesini içerir. Reys, Rybolt, Bestgen \& Wyatt (1982) tarafından gerçekleştirilen çalışmada (347 x 6)/43 şeklinde verilen bir problemi 9. sınıf öğrencileri önce 6/43 işlemini yapmanın daha kolay olacă̆ını düşünerek sonucu yaklaşık olarak 7 bulmuşlardır. Daha sonra ise 347 yi 7’ye bölerek sonucu yaklaşık olarak 50 bulmuşlardır (aktaran, Greeno, 1991, s. 172). 
3) Niceliksel yargı ve çıkarım: Sayı duyusunun kanıtı olarak görülebilen akı1 yürütmenin diğer bir yönü, sayısal değerlerle nicelikler hakkında çıkarımlar yapmak ve bunlarla ilgili değerlendirme yapmaktır. Schoenfeld (1988) tarafından gerçekleştirilen çalışmada 36 asker taşıyabilen otobüslerle 1128 askerin taşınacağı ve bunun için kaç otobüse ihtiyaç olduğuyla ilgili problemde öğrenciler tarafından en çok seçilen cevabın 31 ve kalanın 12 olduğu ifade edilmektedir. Bu da öğrencilerin bu sayıların ne hakkında olduğunu ve ne anlama geldiğini düşünmediklerini ve doğrudan bir aritmetik işlemi uyguladıklarını göstermektedir (aktaran, Greeno, 1991, s. 172-173).

Reys \& Yang (1998), sayı duyusunu "bir kişinin sayı ve işlemler hakkındaki genel anlayışı, esnek yöntemlerle matematiksel yargılar yapmak ve sayıları ve işlemleri yönetmek için kullanışlı stratejiler geliştirmek için kullanılan yetenek anlayışı, bilgilerin iletilmesi, işlenmesi ve yorumlanması için sayısal ve niceliksel yöntemler kullanma yeteneği ve eğiliminin yansıtılması" olarak tanımlamakta ve sayı duyusunun bileşenlerini şu şekilde açıklamaktadır: Birden fazla sayı temsilini kullanma, sayıların göreceli ve mutlak büyüklüklerini tanıma, kıyaslama noktalarını seçme ve kullanma, sayıları ayrıştırabilme ve yeniden düzenleyebilme, sayıların işlemler üzerindeki etkilerini anlayabilme, esnek ve uygun bir şekilde zihinsel hesaplama ve tahmin yapabilme.

Reys ve diğerleri (1999), sayıların anlamlı birimler olduğunu ve matematiksel manipülasyonların sonuçlarının anlamlı olmasının beklendiğini ifade etmişlerdir. Sayıları bu şekilde tanıyanlar, sayısal işlemlerin sonuçlarının makullüğünü değerlendirmek için sürekli olarak çeşitli iç kontrol ve dengelerden yararlanacaklarını belirtmişlerdir. Yaptıkları çalışmada 6 tane sayı duyusu bileşeni belirlemişlerdir. Bunlar,

1) Sayıların anlam ve büyüklüğünün anlaşılması: $2 / 5$ sayısını $1 / 2$ sayısıyla nasıl kiyaslarsinız?

2) Sayıların eşdeğer temsillerini anlama ve kullanma: $2 / 5$ 'nin temsil edilebileceği farklı yolları gösterin.

3) İşlemlerin anlamını ve etkisini anlama: 750/0,98 işleminin sonucu 750 'den fazla mı yoksa az mıdır?

4) Eşdeğer ifadelerin anlaşılması ve kullanılması: 70/0,5 ve 70x2 işlemlerinin sonuçları aynı mıdır değil midir?

5) Zihinsel hesaplama, yazılı hesaplama ve hesap makinesi kullanımı için esnek hesaplama ve sayma stratejileri: Sayıların ve işlemlerin anlamını kullanarak 6x98 işlemini zihinden yapabilir misin?

6) Ölçmede referans (kıyaslama) noktası kullanma: Büyük bir nesnenin yüksekliğini nasıl tahmin edebilirsin? Yardım için bir "kıyaslama" veya "referans noktasi" kullanabilir misin?

Yang \& Tsai (2010) yaptıkları çalışmada sayı duyusu bileşenlerini aşağıdaki şekilde sınıflandırmışlardır.

1) Sayıların temel anlamını anlama: Tam sayılar (tek ve çift sayılar, asal sayılar gibi), kesirler (basit, bileşik kesirler gibi), ondalık sayılar ve aralarındaki ilişkilerde dahil olmak üzere sayı sistemini anlamayı içerir (McIntosh ve diğerleri,1992 aktaran, Yang \& Tsai, 2010, s. 113).

2) Göreli sayı büyüklügünü anlama: Sayıların yaklaşık değerlerini tahmin edebilmeyi içerir. 17/33 ve 18/37 kesirleri karşılaştırıldığında öğrenciler yazılı metotlara 
gereksinim duymadan 1/2 kesrini referans alarak anlamlı ve esnek bir yöntem kullanarak kıyaslayabilirler.

3) Sayıların farklı temsillerini kullanabilme: Bir öğrencinin problemleri farklı durumlarda çözmek için resimsel gösterimler, sembolik temsiller gibi farklı temsil biçimlerini kullanabilmesi anlamına gelir (Yang \& Huang, 2004 aktaran, Yang \& Tsai, 2010, s. 113).

4) İşlemlerin sayılar üzerindeki etkisini anlama: Öğrencilerin dört temel işlemin hesaplama sonuçlarını nasıl etkilediğini anlamasıdır (McIntosh ve diğerleri, 1992 aktaran, Yang \& Tsai, 2010, s. 113). Örneğin $1098 \times 0.88$ ve 825/0,98 sonuçların1 tahmin etmeleri istendiğinde yazılı işlemlere gereksinim duymazlar. Öğrencilerin çarpmanın her zaman çarpanlardan daha büyük bir sonuç vermediğini ve bölmenin daima bölünenden daha küçük bir sayı vermediğini anlamalarıdır (Greer, 1987 aktaran, Yang \& Tsai, 2010, s. 113).

5) Bir hesaplama sonucunun makul olup olmadığını yargılayabilme: Öğrencilerin problemleri çözmek için esnek stratejiler (zihinsel veya tahmini stratejiler gibi) geliştirebilmesi ve hesaplama sonucunun uygun olup olmadiğına karar verebilmesidir (McIntosh ve diğerleri, 1992 aktaran, Yang \& Tsai, 2010, s. 113).

Sayı duyusu gelişmemiş bireyler sayılar ve işlemlerle hesaplama yaparken önceden edindikleri kuralları uygulamaktadırlar. Fakat sayı duyusu gelişmiş bireyler sayı ve işlemlere daha esnek bir yaklaşım sergileyebilmektedirler (Ulusoy \& Şahiner, 2016). Öğrencilere sayıları yorumlayabilecek, hesaplamaların yaklaşık değerlerini tahmin edebilecek becerilerin küçük yaşlardan itibaren kazandırılması, onların ileriki yaşamlarında kullanabilecekleri pratik bir yöntem kazanmalarını sağlayacaktır. Bu nedenle öğrencilerin sayı duyusu becerilerini geliştirebilmeleri için öğretmenlerin ilkokul ve ortaokulda derslerde ilgili kazanımların üzerinde dikkatle durması oldukça önemlidir. Öğrencilerin sayı duyularının gelişmesi ve zihinden işlem yapmalarının teşvik edilmesi onların yaratıcılığını, anlık hesaplama ve çıkarımlarda bulunmalarını geliştirmelerine yardımcı olacaktır.

Alan yazında sayı duyusuyla ilgili farklı çalışmaların yapıldığı görülmektedir. Ortaokul öğrencilerinin doğal sayılar, ondalık sayılar, kesirler, yüzdeler, üslü sayılar konularında kullandıkları sayı duyusu stratejilerini belirlemek amacıyla yapılan çalışmaların sonucunda öğrencilerin soruları daha çok kural temelli stratejileri kullanarak cevapladıkları, sayı duyusu kullanımının düşük olduğu, sayı duyusu kullanımının cinsiyete göre farklılık göstermediği ancak sınıf düzeyinin ve matematik başarısının sayı duyusu kullanımı üzerinde etkili olduğu belirlenmiştir (Bayram, 2013; Er \& Dinç-Artut, 2015; Harç, 2010; İymen \& Duatepe-Paksu, 2015; Kayhan-Altay, 2010; Yapıc1, 2013). Şengül \& Gülbağcı (2013) tarafından yapılan çalışmada 7. ve 8. sınıf öğrencilerinin sayı duyusu ile matematik öz yeterlikleri arasındaki ilişki incelenmiş ve çalışmanın sonucunda öğrencilerin sayı duyusu performanslarının düşük seviyede olduğu görülmüştür. Sınıf seviyeleri arasında sayı duyusu kullanımı bakımından anlamlı bir fark olmadığı belirlenmiştir. Ayrıca sayı duyusu ile matematik öz yeterliği arasında orta seviyede bir ilişki olduğu tespit edilmiştir. Bunların dışında öğretmen ve öğretmen adaylarının sayı duyusu stratejilerini kullanma durumlarını incelemek amacıyla yapılan çalışmalarda sayı duyusu performanslarının düşük seviyede olduğu ve sayı duyusu 
stratejilerinin orta düzeyde kullanıldığı belirlenmiştir (Kayhan-Altay \& Umay, 2011; Şengül \& Gülbağc1-Dede, 2014;).

Alan yazın incelendiğinde sayı duyusu ile ilgili farklı sayı gruplarına yönelik çalışmaların yapıldığı görülmektedir. Doğal sayılar ve tam sayılar kümeleri günlük yaşantımızda bazı problemlerin çözümünde yetersiz kalırlar. Bu nedenle doğal sayılar kümesi çıkarma işlemi yapılabilecek şekilde genişletilerek tam sayılar ve tam sayılar kümesi de bölme işlemi yapılabilecek şekilde genişletilerek rasyonel sayılar elde edilmiştir (Baykul, 2014). Dolayısıyla rasyonel sayılara ilişkin sayı duyusuna sahip olmak günlük yaşamın kalitesi açısından önemlidir. Alan yazında doğrudan rasyonel sayılar konusuna yönelik sayı duyusu kullanımlarının incelendiği bir çalışmaya rastlanılmamıştır. Bu bağlamda, bu çalışmanın alan yazındaki bu boşluğu doldurma konusunda matematik eğitimi alanına katkı sağlayacağı düşünülmektedir.

Araştırmanın problemi “7. sınıf öğrencilerinin rasyonel sayılar konusunda sayı duyusu kullanma durumları nedir?" şeklinde ifade edilebilir. Çalışmada ayrıca "7. sınıf öğrencilerinin rasyonel sayılar konusunda sayı duyusu kullanımlarının sayı duyusu bileşenlerine, cinsiyete ve okul öncesi eğitim alma durumuna göre dağılımı nasıldır?" alt problemlerine de cevap aranmıştır.

\section{Yöntem}

$\mathrm{Bu}$ bölümde araştırmanın deseni, çalışma grubu, veri toplama araç ve teknikleri ve verilerin çözümlenmesine ilişkin bilgilere yer verilmiştir.

\section{Araştırmanın Deseni}

$\mathrm{Bu}$ çalışma nitel bir araştırma olup betimsel araştırma yöntemlerinden durum çalışması modeli kullanılmıştır. McMillan (2000), durum çalışmalarını "bir yada daha fazla olayın, ortamın, programın, sosyal grubun yada diğer birbirine bağlı sistemlerin derinlemesine incelendiği yöntem" olarak tanımlamaktadır (Akt: Büyüköztürk, Çakmak, Akgün, Karadeniz \& Demirel, 2016).

\section{Çalışma Grubu}

Araştırmanın çalışma grubunu 2016-2017 eğitim öğretim yılında Manisa ilindeki bir devlet okulunda öğrenim görmekte olan 38 ortaokul 7. sınıf öğrencisi oluşturmaktadır. Araştırmada rastgele olmayan örnekleme tekniklerinden uygun örnekleme yöntemi kullanılarak katılımcılar belirlenmiştir. Araştırmada uygun örnekleme yönteminin seçilmesinin nedeni, bu yöntemle zaman, para ve işgücü açısından var olan sınırlılıklar nedeniyle örneklemin kolay ulaşılabilir ve uygulama yapılabilir birimlerden seçilmesidir. Çalışma grubunda 19 kız ve 19 erkek öğrenci yer almaktadır. Öğrencilerin 29'u okul öncesi eğitim almış olup, 9 öğrenci ise okul öncesi eğitim almadığını ifade etmiştir. Araştırmaya katılan öğrencilerin çoğunun ailesinin sosyo-ekonımik durumu orta düzeydedir. Çalışma grubunu oluşturan öğrenciler zayıf, orta, iyi gibi farklı düzeyde matematik başarısına sahiptirler. Öğrencilere başarı testi uygulanmadan önce çalışmanın amacı hakkında bilgi verilmiştir. Çalışmaya katılımın gönüllük esasına dayalı olduğu belirtilmiş olup isteyenlerin çalışmaya katılmayabileceği ifade edilmiştir. 


\section{Veri Toplama Araç ve Teknikleri}

$\mathrm{Bu}$ çalışmada, hazırlanan ölçme aracına uygunluk açısından Reys ve diğerleri'nin (1999) belirlediği "Sayıların eşdeğer temsillerini anlama ve kullanma" ile "Eşdeğer ifadelerin anlaşılması ve kullanılması" bileşenleri "Sayıların eşdeğer temsillerinin anlaşılması" şeklinde ve "Sayıların anlam ve büyüklüğünün anlaşılması" ile "Ölçmede referans (kıyaslama) noktası kullanma" bileşenleri de "Sayıların anlamının ve büyüklüğünün anlaşılması" şeklinde tek bileşen olarak ele alınmıştır. Buna göre bu çalışma kapsamında ele alınan dört sayı duyusu bileşeni; sayıların eşdeğer temsillerinin anlaşılması, sayıların anlamının ve büyüklüğünün anlaşılması, işlemlerin sayılar üzerindeki etkisi, zihinsel / esnek hesaplama olarak isimlendirilmişstir. Bu çalışmadan elde edilecek sonuçların alanyazındaki benzer çalışmaların sonuçları ile karşılaştırılabilir olması açısından Reys ve diğerleri’nin (1999) sınıflandırması kullanılmıştır.

Alan yazındaki sayı duyusuyla ilgili hazırlanmış olan başarı testleri ve MEB (2013) 7.sınıf öğretim programındaki rasyonel sayılara yönelik kazanımlar dikkate alınarak araştırmacılar tarafından sayı duyusu başarı testi hazırlanmıştır. Sayı duyusu başarı testi dört sayı duyusu bileşeni kapsamında hazırlanan toplam 14 sorudan oluşmaktadır. Belirlenen sayı duyusu bileşenleri aşağıdaki gibidir:

Sayıların Eşdeğer Temsillerinin Anlaşılması: Sayıları farklı gösterimlerle tekrar yazabilme becerisini içerir. 50 sayısını 100/2 şeklinde yazabilme, 2/5 sayısını farklı şekilde tekrar yazabilme gibi.

Sayıların Anlamının Ve Büyüklüğünün Anlaşılması: Sayıların göreceli büyüklüğünü tahmin etmeyi içerir. Referans noktası kullanarak sayıları karşılaştırma becerisini içerir. Ayrıca verilen bir uzunluğu referans alabilme becerisini içerir. Rasyonel sayıların tama, yarıma ne kadar yakın olduğunu yorumlayabilme, negatif ve pozitif sayıları bilme, belirli bir uzunluk verilip sayıları bu uzunluğa göre yazabilme gibi.

İşlemlerin Sayılar Üzerindeki Etkisi: Dört işlemin ve sayıların hesaplamalar üzerinde etkisini bilme becerisidir. Bölme ve çarpmanın sayıları büyütüp küçültmesini anlayabilme gibi.

Zihinsel / Esnek Hesaplama: Verilen işlemlerin sonuçlarının yaklaşık veya tam değerlerini zihinden hesaplayabilme becerisidir. 5/6+2/5 işleminin sonucunu bulurken 5/6' in 1'e yakın, 2/5'nin yarıma yakın olduğunu düşünerek yaklaşık sonucu hesaplama gibi.

Başarı testindeki yer alan soruların amaca hizmet edip etmediğini belirlemek için iki matematik eğitimi alan uzmanının ve iki matematik öğretmeninin görüşüne başvurulmuştur. Alan uzmanlarından ve öğretmenlerden başarı testinde yer alan soruların ilgili kazanımlara ve sayı duyusu bileşenlerine uygun olduğu ve soruların sözel ifadelerinde küçük değişiklikler yapılabileceği yönünde alınan geri bildirimler doğrultusunda başarı testinde gerekli düzeltmeler yapılmıştır. Ayrıca iki ortaokul 7. sınıf öğrencisi üzerinde pilot uygulama yapılmıştır. Asıl uygulamada ise çalışma grubunu oluşturan öğrencilere başarı testini cevaplamaları için 2 ders saati $(40 \mathrm{dk}+40 \mathrm{dk}=80 \mathrm{dk})$ süre verilmiştir. Öğrencilerden sorulara verdikleri cevapları ayrıntılı bir şekilde açıklamaları istenmiştir. 


\section{Verilerin Çözümlenmesi}

Verilerin çözümlenmesi aşamasında içerik analizi kullanılmıştır. İçerik analizi, belirli metnin kitabın belgenin içeriğinde gizli kavram, ilke ve özellikleri anlama ve anlatma amacı ile yapılan bir taramadır (Karasar, 2016).

Öğrencilerin sorulara verdikleri cevaplar içerik analizine göre kategorilere ayrılmış ve oluşan kategoriler "kural temelli", "sayı duyusu", "yanlış" ve "boş" şeklinde ifade edilmiştir. Verilerin sınıflandırılması sonucunda oluşan kategorilerin açıklamaları aşağıdaki gibidir.

Sayı Duyusu: Öğrencinin sorunun doğru cevabını bulurken sayı duyusu bileşenlerini kullanması.

Kural Temelli: Öğrencinin sorunun doğru cevabını bulurken kural temelli işlemler yapması.

Yanlış: Öğrencinin sorunun cevabını yanlış bulması.

Boş: Sorunun cevap bölümüne hiçbir şeyin yazılmaması.

Örneğin " $25 \times 36$ ișleminin sonucunu bulunuz" sorusunu “(100/4)x36=(36x100)/4=3600/4=900” şeklinde cevaplayan öğrencinin çözümü 25 sayısının farklı temsilini kullandığı için "sayı duyusu", 25 tane 36'yı toplayarak "36+36+36+ .. $+36=900 "$ şeklinde cevaplayan öğrencinin çözümü çarpmanın tekrarlı toplama tanımını kullandığı için "kural temelli", " $(20 \times 30)+(5 \times 6)=600+30=630 "$ şeklinde cevaplayan öğrencinin çözümü çarpma işlemini yanlış yaptığı için "yanlış” ve soruyu boş bırakan öğrencinin çözümü "boş” kategorisinde değerlendirilmiştir.

Oluşturulan kategoriler ve açıklamaları bir başka matematik öğretmeni ile paylaşılarak öğrencilerin cevaplarını söz konusu kategorilere göre analiz etmesi istenmiştir. Araştırmacı ile matematik öğretmeninin, cevapların ilgili kategorilere dağılımı konusunda görüş birliği ve görüş ayrılığı olan sorular belirlenmiş ve Miles \& Huberman (1994) tarafından önerilen Güvenirlik = Görüş birliği / (Görüş birliği + Görüş ayrılığı) formülü kullanılarak araştırmanın güvenirliği $\% 90$ olarak hesaplanmıştır. Güvenirlik hesaplarının \%70'in üzerinde çıkması, araştırma için güvenilir kabul edilmektedir. Uygulamadan elde edilen veriler tablo haline getirilmiştir. Bir öğrenci hem sayı duyusu hem de kural temelli bir çözüm yapmış ise bu durum sayı duyusu ve kural temelli kategorilerinin her ikisinin frekanslarına da yansıtılmıştır.

\section{Bulgular}

$\mathrm{Bu}$ kısımda öğrencilerin başarı testine verdikleri cevaplar incelenerek alt problemlere ilişkin analizlere yer verilmiştir.

\section{Sınıf Öğrencilerinin Rasyonel Sayılar Konusunda Sayı Duyusu Kullanımlarının Cinsiyete Göre Dağılımı}

Öğrencilerin başarı testine verdikleri cevapların cinsiyet değişkenine göre dağglımı incelenmiş ve sonuçlar Tablo 1'de sunulmuştur. 
Tablo 1

Cinsiyete Göre Sayı Duyusu ve Kural Temelli Çözümlerin Dağılımı

\begin{tabular}{|c|c|c|c|c|c|c|c|c|c|c|c|c|c|c|c|c|}
\hline & Soru No & 1 & 2 & 3 & 4 & 5 & 6 & 7 & 8 & 9 & 10 & 11 & 12 & 13 & 14 & Toplam \\
\hline \multirow{2}{*}{$\mathrm{K} 1 \mathrm{z}$} & Sayı Duyusu & 1 & 1 & 3 & 1 & 4 & 2 & 0 & 2 & 8 & 2 & 5 & 4 & 4 & 1 & 38 \\
\hline & Kural Temelli & 7 & 9 & 0 & 3 & 2 & 8 & 12 & 7 & 1 & 6 & 5 & 0 & 0 & 3 & 63 \\
\hline \multirow{2}{*}{ Erkek } & Sayı Duyusu & 0 & 0 & 2 & 0 & 1 & 0 & 0 & 0 & 7 & 0 & 3 & 0 & 2 & 0 & 15 \\
\hline & Kural Temelli & 6 & 5 & 1 & 1 & 2 & 3 & 7 & 1 & 0 & 0 & 4 & 0 & 0 & 3 & 33 \\
\hline
\end{tabular}

Tablo 1 incelendiğinde; cinsiyet açısından araştırmaya katılan kızların sayı duyularını erkeklere göre daha çok kullandıkları görülmektedir. Kız öğrencilerin 101 doğru cevabın 38'inde sayı duyusu, 63'ünde ise kural temelli yöntemleri kullandıkları görülmektedir. Erkek öğrencilerin ise 48 doğru cevabın 15'inde sayı duyusu bileşenlerini, 33'ünde ise kural temelli yöntemleri kullandıkları görülmektedir.

\section{Sınıf Öğrencilerinin Rasyonel Sayılar Konusunda Sayı Duyusu Kullanımlarının Okul Öncesi Eğitim Alma Durumuna Göre Dağılımı}

Öğrencilerin başarı testine verdikleri cevapların okul öncesi eğitim alma durumuna göre dağılımı incelenmiş ve sonuçlar Tablo 2'de sunulmuştur.

Tablo 2

Okul Öncesi Eğitim Alma Durumuna Göre Sayı Duyusu ve Kural Temelli Çözümlerin Dă̆ılımı

\begin{tabular}{|c|c|c|c|c|c|c|c|c|c|c|c|c|c|c|c|c|}
\hline & Soru No & 1 & 2 & 3 & 4 & 5 & 6 & 7 & 8 & 9 & 10 & 11 & 12 & 13 & 14 & Toplam \\
\hline \multirow{2}{*}{ Alan } & Sayı Duyusu & 1 & 1 & 5 & 1 & 4 & 2 & 0 & 2 & 10 & 2 & 7 & 3 & 5 & 1 & 44 \\
\hline & Kural Temelli & 9 & 12 & 1 & 3 & 4 & 9 & 13 & 7 & 1 & 5 & 6 & 0 & 0 & 4 & 74 \\
\hline \multirow{2}{*}{ Almayan } & Sayı Duyusu & 0 & 0 & 0 & 0 & 1 & 0 & 0 & 0 & 5 & 0 & 1 & 1 & 1 & 0 & 9 \\
\hline & Kural Temelli & 4 & 2 & 0 & 1 & 0 & 2 & 6 & 1 & 0 & 1 & 3 & 0 & 0 & 2 & 22 \\
\hline
\end{tabular}

Tablo 2 incelendiğinde; okul öncesi eğitim alan öğrencilerin soruların çözümünde sayı duyusunu, okul öncesi eğitim almayan öğrencilere göre daha fazla kullandıkları görülmektedir.

\section{Sınıf Öğrencilerinin Rasyonel Sayılar Konusunda Sayı Duyusu} Kullanımlarının Sayı Duyusu Bileşenlerine Göre Dağılımı

Sayıların eşdeğer temsilleri sayı duyusu bileşeninin analizi. Sayı duyusu bileşenlerinden sayıların eşdeğer temsillerinin kullanımına yönelik başarı testinde 1, 10 ve 11. sorular sorulmuş ve analizleri Tablo 3'de sunulmuştur. 
Tablo 3

Sayıların Eşdeğer Temsilleri Sayı Duyusu Bileşeni Kullanımının Sorulara Göre Dă̆ılımı

\begin{tabular}{llllll}
\hline & Soru No & 1 & 10 & 11 & Toplam \\
\hline \multirow{2}{*}{ Doğru } & Sayı Duyusu & 1 & 2 & 8 & 11 \\
\cline { 2 - 6 } & Kural Temelli & 13 & 6 & 9 & 28 \\
\hline Yanlış & & 18 & 16 & 12 & 46 \\
\hline Boş & & 6 & 15 & 9 & 30 \\
\hline
\end{tabular}

Tablo 3 incelendiğinde; 1. ve 10. sorularda doğru cevap veren öğrencilerin çoğunun kural temelli çözüm yaptıkları görülmektedir. 11. soruda ise doğru cevap veren öğrencilerin yarısının sayı duyusu bileşenini, yarısının ise kural temelli yöntemleri kullandıkları görülmektedir. $\mathrm{Bu}$ bölümle ilgili 11. soruda öğrencilerden 5/8 kesrinin eşdeğer temsilini kullanarak şeklin istenilen kısmını boyaması beklenmektedir. Tablo 3 incelendiğinde öğrencilerin neredeyse yarısı 11. soruya doğru cevap vermiştir. Doğru cevap veren öğrencilerin yarısı sayı duyusu bileşeni kullanmıştır. 031 kodlu öğrenci verilen kesre eşdeğer temsilde başka bir kesir yazarak soruyu cevaplamıştır. 031 kodlu öğrencinin cevabı aşağıdaki gibidir.

Şekil 1. 031 Kodlu Öğrencinin 11. Soruda Kullandığg Sayı Duyusu Bileşeni

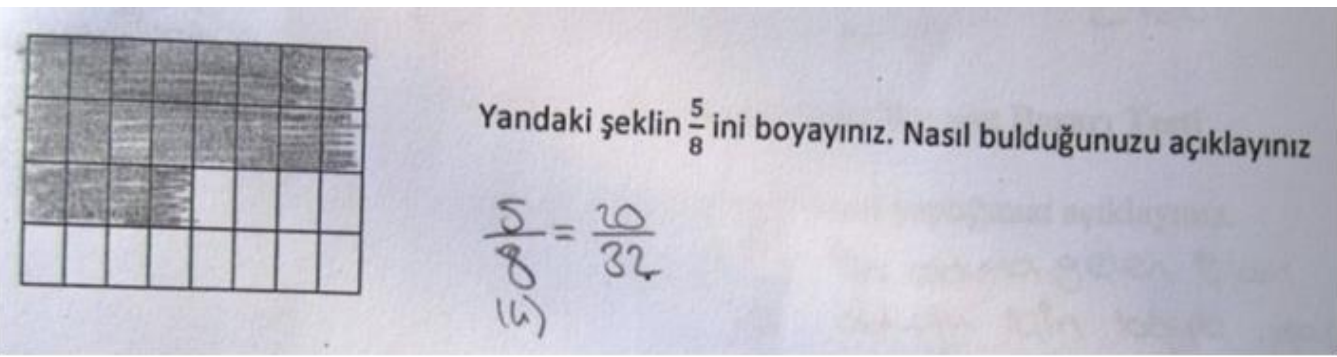

10. soruda öğrencilerden 25 sayısının yerine eşdeğer temsili olan 100/4 ifadesini kullanması beklenmektedir. Tablo 3 incelendiğinde sadece 2 öğrencinin bu sayı duyusu bileşenini kullandığg görülmektedir. Öğrencilerin büyük çoğunluğunun bu soruya doğru cevap veremedikleri görülmektedir. 10. soruya sayı duyusu bileşeni kullanarak doğru cevap veren 015 kodlu öğrencinin cevabı aşağıdaki gibidir.

Şekil 2. 015 Kodlu Öğrencinin10. Soruda Kullandığı Sayı Duyusu Bileşeni

) 25 x 36 işleminin sonucunu çarpmadan bulunuz. Sonucu nasıl bulduğunuzu açıklayınız. ( Ipucu: 25 sayısını rasyonel sayı şeklinde yazmaya çalışınız)

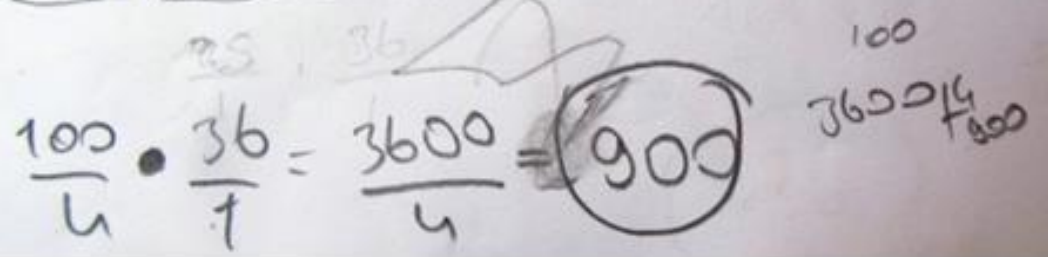


018 kodlu öğrencinin 10. soruyu hem sayı duyusu bileşenini hem de kural temelli yöntem kullanarak doğru cevapladığı görülmektedir. 018 kodlu öğrencinin cevabı aşağıdaki gibidir.

Şekil 3. 018 Kodlu Öğrencinin Cevabı

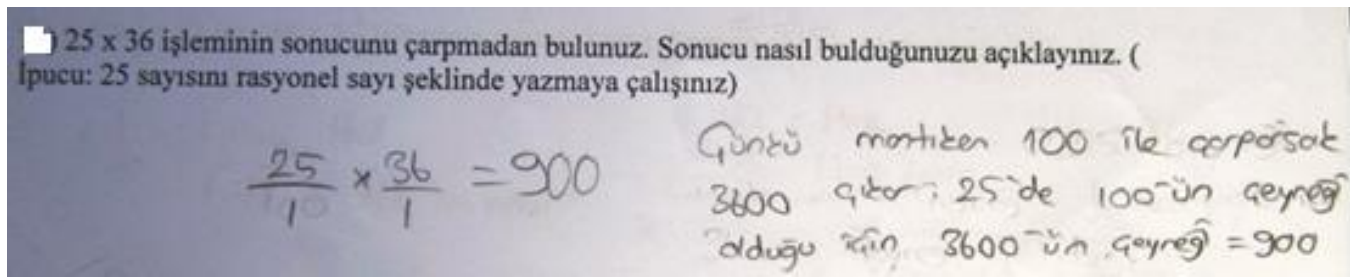

024 kodlu öğrenci 10. soruda kural temelli yöntem kullanarak doğru cevaba ulaşmıştır. 024 kodlu öğrencinin cevabı aşağıdaki gibidir.

Şekil 4. 024 Kodlu Öğrencinin Cevab1

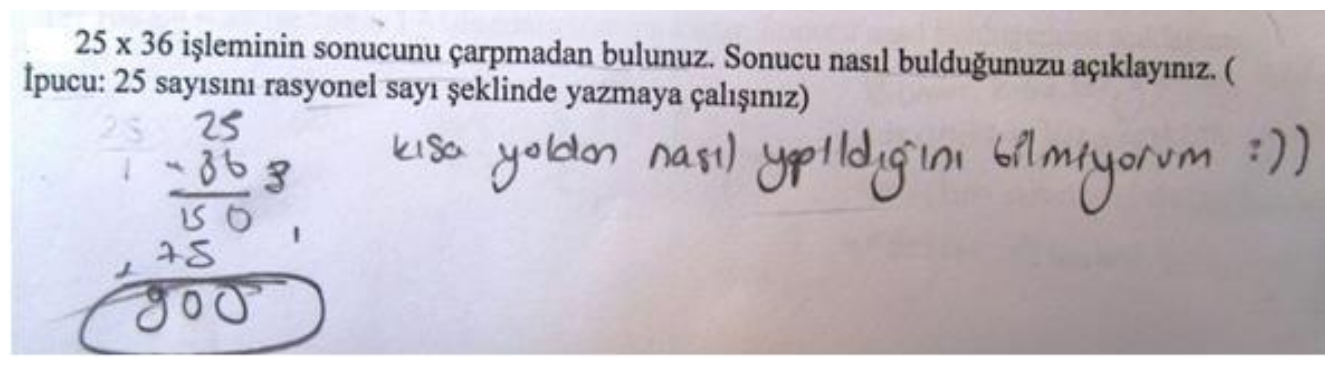

06 kodlu öğrenci ise diğer öğrencilerden farklı bir kural temelli yöntem kullanarak doğru cevabı bulabilmiştir. 06 kodlu öğrencinin cevabı aşağıdaki gibidir.

Şekil 5. 06 Kodlu Öğrencinin Cevabı

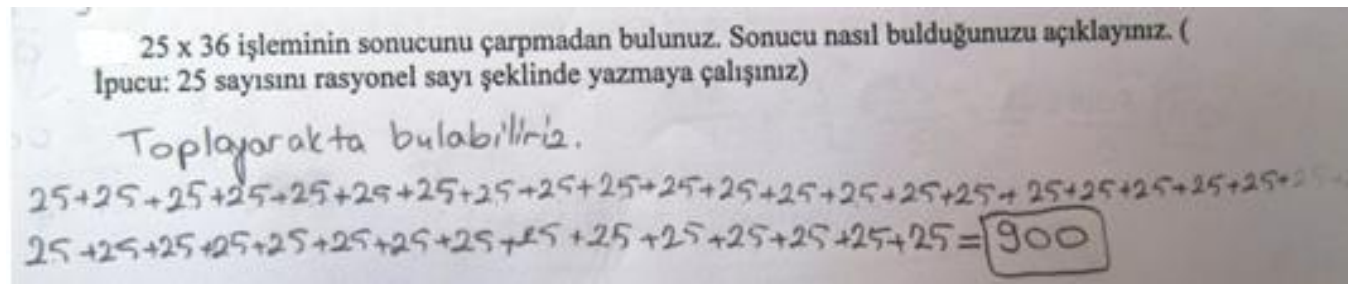

Şekil 5'e göre 06 kodlu öğrenci çarpmanın tekrarlı toplamaya dayalı tanımından yararlanmıştır.

Sayıların eşdeğer temsillerini yazmaya yönelik 1. soruda öğrencilerin $3 / 2$ kesrinin eşdeğer temsili olan 1 tam 1/2 tam sayılı kesrini ya da 1,5 ondalık gösterimini kullanması beklenmektedir. Tablo 3 incelendiğinde 1. soruyu sayı duyusu bileşenini kullanarak doğru cevaplayabilen sadece 1 öğrenci olduğu görülmektedir. 018 kodlu öğrencinin cevabı aşă̆ıdaki gibidir. 
Şekil 6. 018 Kodlu Öğrencinin Cevabı

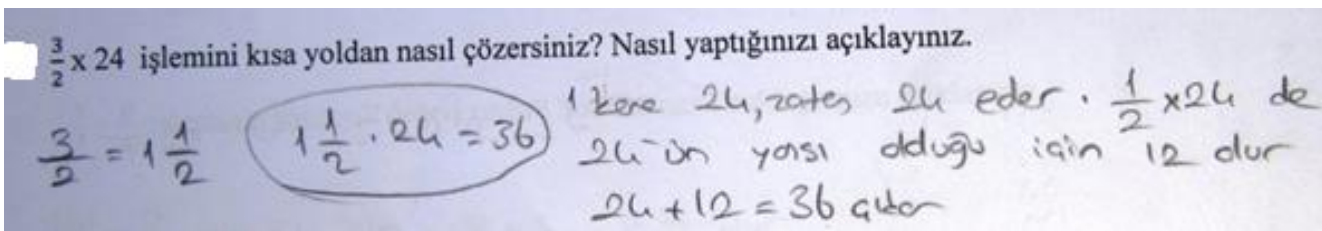

Öğrencilerin çoğu 1. sorunun doğru cevabına ulaşmak için kural temelli yöntemleri kullanmışlardır. Fakat yanlış cevap verenlerin büyük çoğunluğunun rasyonel sayılarda çarpma işlemi yaparken payda eşitledikleri için doğru cevaba ulaşamadıkları görülmektedir. Bu duruma örnek olarak 037 kodlu öğrencinin cevabı aşağıdaki gibidir.

Şekil 7. 037 Kodlu Öğrencinin Cevabı

1) $\frac{3}{2} \times 24$ işlemini kısa yoldan nasıl çözersiniz? Nasıl yaptığınızı açıklayınız.

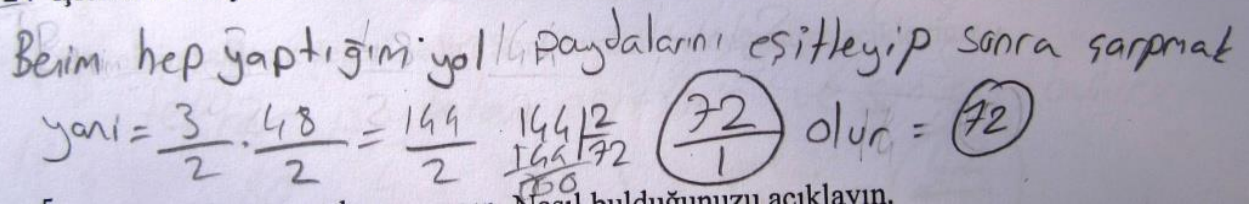

Sayıların anlam ve büyüklüğünün anlaşılması sayı duyusu bileşeninin analizi. Sayı duyusu bileşenlerinden sayıların anlam ve büyüklüğünü anlamaya yönelik başarı testinde 2, 8, 12 ve 13. sorular sorulmuş ve analizleri Tablo 4'de sunulmuştur.

Tablo 4

Sayıların Anlamının ve Büyüklüğünün Anlaşılması Sayı Duyusu Bileşeni Kullanımının Sorulara Göre Dă̆glımı

\begin{tabular}{lllllll}
\hline & Soru No & 2 & 8 & 12 & 13 & Toplam \\
\hline \multirow{2}{*}{ Doğru } & Sayı Duyusu & 1 & 2 & 4 & 6 & 13 \\
\cline { 2 - 7 } & Kural Temelli & 14 & 8 & 0 & 0 & 22 \\
\hline Yanlış & & 12 & 22 & 26 & 19 & 79 \\
\hline Boş & & 11 & 6 & 8 & 13 & 38
\end{tabular}

Tablo 4 incelendiğinde; verilen iki rasyonel sayı arasına bir rasyonel sayı yazmaya yönelik 2. soruya öğrencilerin yaklaşık yarısının doğru cevap verebildiği görülmektedir. 2. soruya doğru cevap veren öğrencilerden sadece 1 tanesi sayı duyusu bileşeni kullanmış diğerleri ise kural temelli yöntemler kullanmışlardır. 2. soruyu sayı duyusu bileşeni kullanarak doğru cevaplayan 018 kodlu öğrencinin cevabı aşağıdaki gibidir. 
Şekil 8. 018 Kodlu Öğrencinin Cevab1

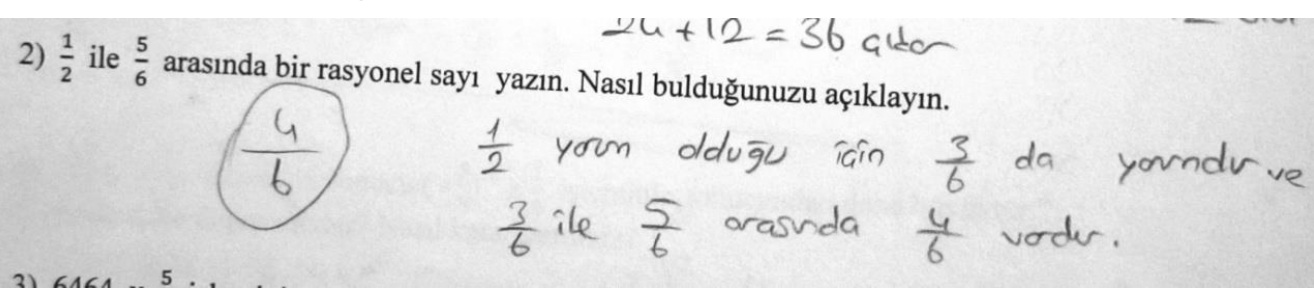

2. sorunun doğru cevabında kural temelli yöntem kullanan öğrencilerin neredeyse hepsi verilen kesri genişleterek doğru sonuca ulaşmıştır. Bu duruma örnek olarak 024 kodlu öğrencinin cevabı aşağıdaki gibidir.

Şekil 9. 024 Kodlu Öğrencinin Cevabı

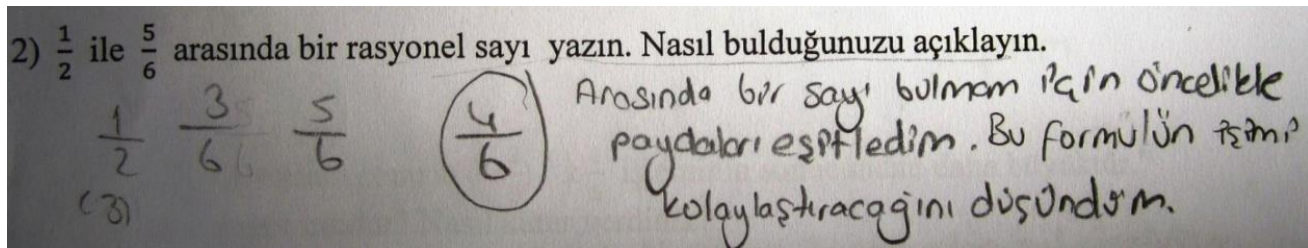

2. soruda yanlış bir yöntem kullanan 027 kodlu öğrencinin cevabı aşağıdaki gibidir.

Şekil 10. 027 Kodlu Öğrenci Cevabı

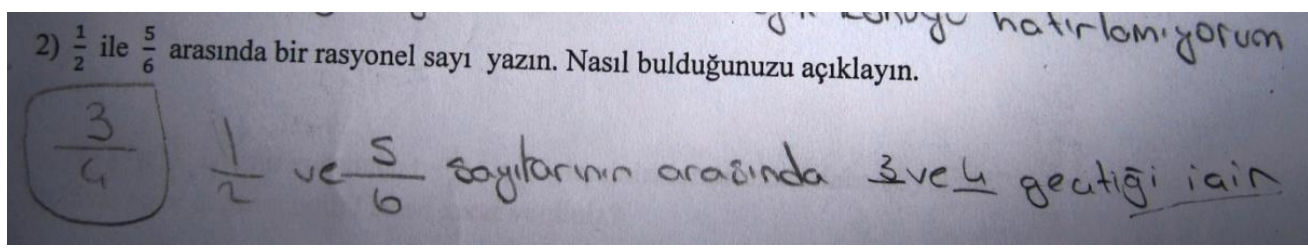

13. soruda öğrencilerden verilen sayıların yarıma veya tama ne kadar yakın olduklarını anlamaları beklenmektedir. Tablo 4 incelendiğinde öğrencilerin çok azının soruya doğru cevap verdiği ve doğru cevap verenlerin hepsinin sayı duyusu bileşenlerini kullandıkları görülmektedir. 037 ve 023 kodlu öğrenciler 13. soruda sayı duyusu bileşenlerini kullanarak doğru cevaba ulaşmışlardır. 037 ve 023 kodlu öğrencilerin cevapları aşağıdadır.

Şekil 11. 037 Kodlu Öğrencinin Cevabı

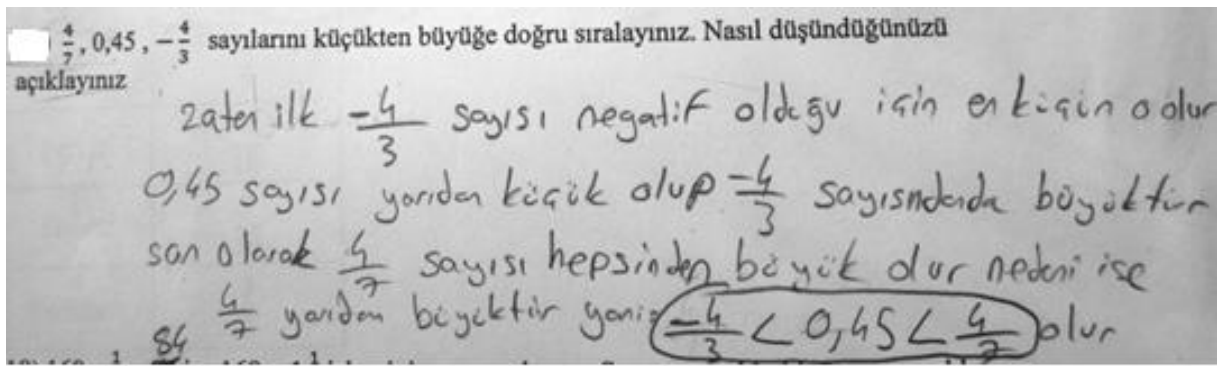


Şekil 12.023 Kodlu Öğrencinin Cevabı

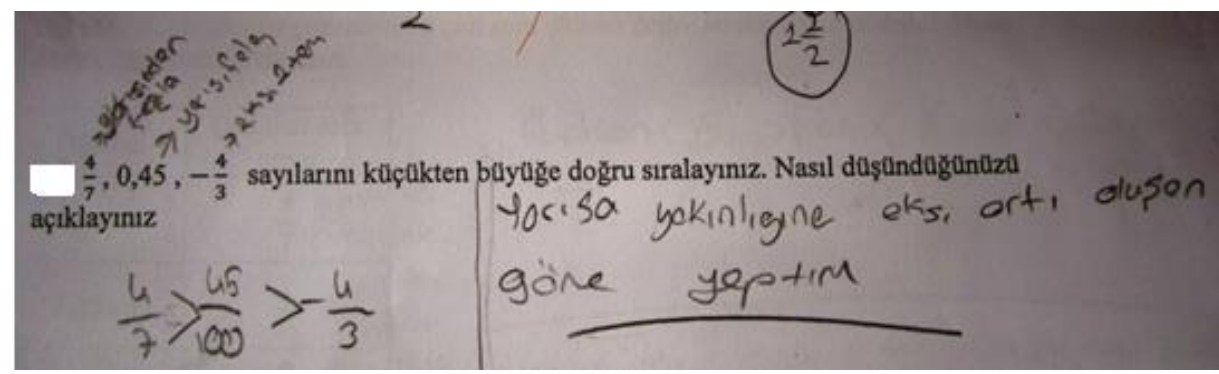

12. soruda öğrencilerin verilen uzunluğu kullanarak sayıları yaklaşık yerlerine yazmaları beklenmektedir. Tablo 4 incelendiğinde 12. soruya öğrencilerin çok azının doğru cevap verdiği görülmektedir. 12. soruya doğru cevap veren öğrencilerin hepsi sayı duyusu bileşenlerini kullanmışlardır. Sayı duyusu bileşeni kullanarak doğru cevap veren 020 kodlu öğrencinin cevabı aşağıdaki gibidir.

Şekil 13. 020 Kodlu Öğrencinin Cevabı

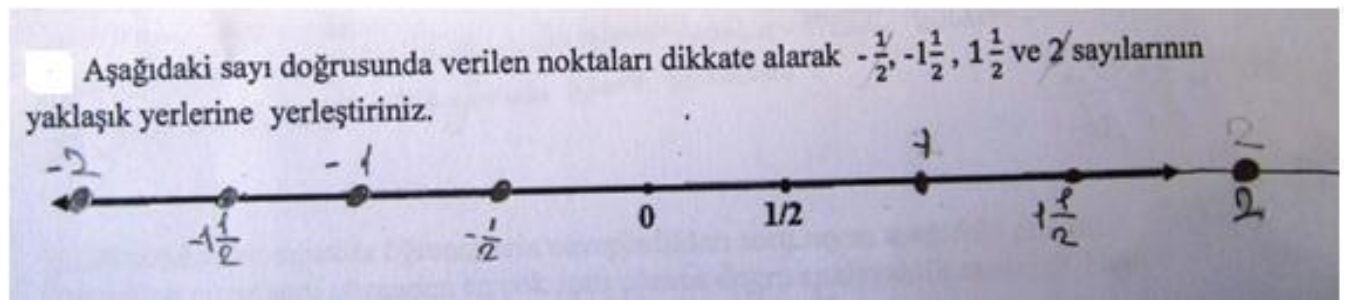

12. soruya yanlış cevap veren öğrencilerin genellikle verilen uzunluğu dikkate almadıkları görülmektedir. Bu duruma örnek olarak 011 kodlu öğrencinin cevabı aşağıdaki gibidir.

Şekil 14. 011 Kodlu Öğrencinin Cevabı

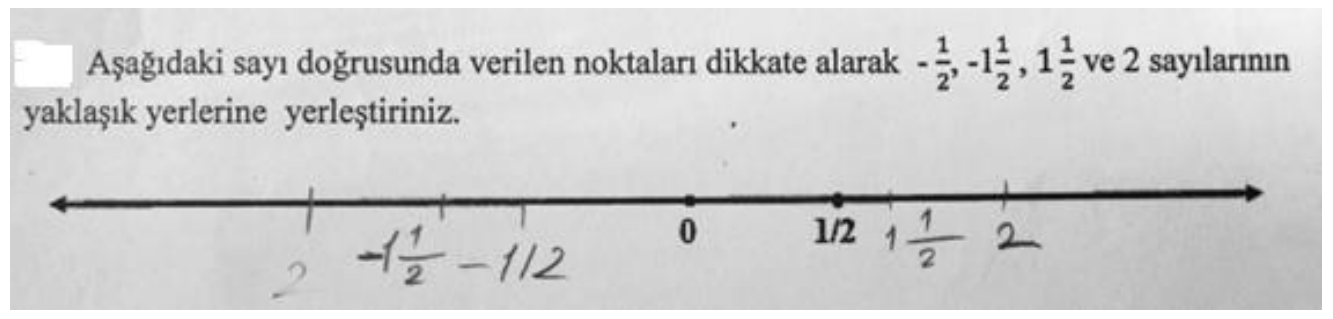

8. soruda öğrencilerin verilen sayıların yarıma veya tama ne kadar yakın olduklarını anlamaları beklenmektedir. Tablo 4 incelendiğinde öğrencilerin yaklaşık yarıs1 8. soruya doğru cevap vermişlerdir. Doğru cevap veren öğrencilerden sadece 2 tanesi sayı duyusu bileşenini kullanmışlardır. Sayı duyusu bileşeni kullanan 023 kodlu öğrencinin cevabı aşağıdaki gibidir. 
Şekil 15. 023 Kodlu Öğrencinin Cevab1

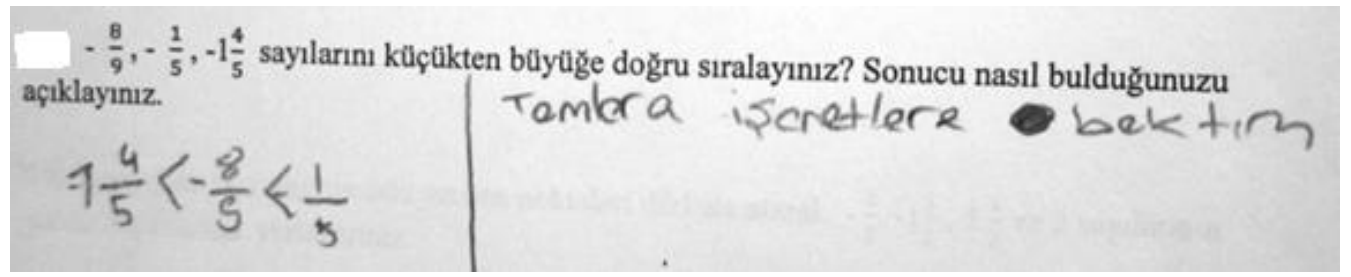

8. soruda kural temelli çözüm kullanan 019 kodlu öğrencinin cevabı aşağıdaki gibidir.

Şekil 16. 019 Kodlu Öğrencinin Cevabı

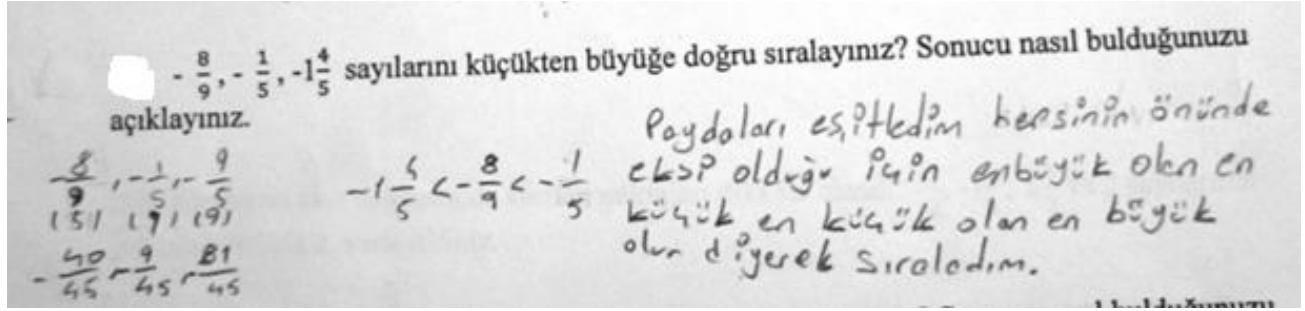

8. soruya yanlış cevap öğrencilerin en çok eksi işaretini dikkate almadıkları için hata yaptıkları görülmektedir. Bu konuyla ilgili 031 kodlu öğrencinin cevabı aşağıdaki gibidir.

Şekil 17. 031 Kodlu Öğrencinin Cevab1

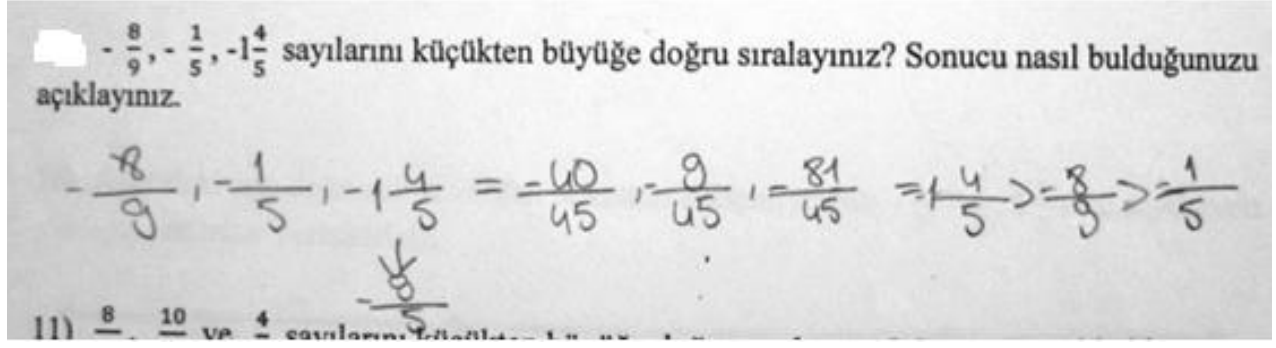


İșlemlerin sayılar üzerindeki etkisi sayı duyusu bileşeninin analizi. Sayı duyusu bileşenlerinden işlemlerin sayılar üzerindeki etkisini anlamaya yönelik başarı testinde 3 , 4 ve 9 . sorular sorulmuş ve analizleri Tablo 5'de sunulmuştur.

Tablo 5

İşlemlerin Sayılar Üzerindeki Etkisi Sayı Duyusu Bileşeni Kullanımının Sorulara Göre Dağılımı

\begin{tabular}{llllll}
\hline & Soru No & 3 & 4 & 9 & Toplam \\
\hline \multirow{2}{*}{ Doğru } & Sayı Duyusu & 5 & 1 & 15 & 21 \\
\cline { 2 - 6 } & Kural Temelli & 1 & 4 & 1 & 6 \\
\hline Yanlış & & 25 & 26 & 14 & 65 \\
\hline Boş & & 7 & 7 & 8 & 22 \\
\hline
\end{tabular}

Tablo 5 incelendiğinde; 3 . ve 9. soruya doğru cevap öğrencilerin çoğunun say1 duyusu bileşeni kullandığ 1 ancak 4. soruyu doğru cevaplayan öğrencilerin büyük bir kısmının ise kural temelli yöntemler kullandığı görülmektedir.

9. soruda öğrencilerden verilen kesirleri tek tek toplamak yerine çarpmanın etkisini kullanarak sonuca ulaşması beklenmektedir. Tablo 5 incelendiğinde öğrencilerin yarısına yakınının 9. soruya doğru cevap verdiği görülmektedir. Doğru cevap veren öğrencilerin bir tanesi hariç soruyu sayı duyusu bileşenlerini kullanarak çözdükleri görülmektedir.036 kodlu ve 024 kodlu öğrencilerin 9. soruya verdikleri cevaplar aşağıdaki gibidir.

Şekil 18. 036 Kodlu Öğrencinin Cevabı

$$
\frac{17}{64}+\frac{17}{64}+\frac{17}{64}+\frac{17}{64}+\frac{17}{64}+\frac{17}{64}+\frac{17}{64}+\frac{17}{64} \text { işleminin sonucunu toplama işleminden farkh bir }
$$
yőntem kullanarak bulunuz. Sonucunnasıl bulduğunuzu açıklayınız

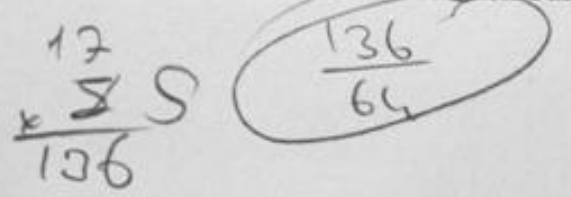

Şekil 19. 024 Kodlu Öğrencinin Cevabı

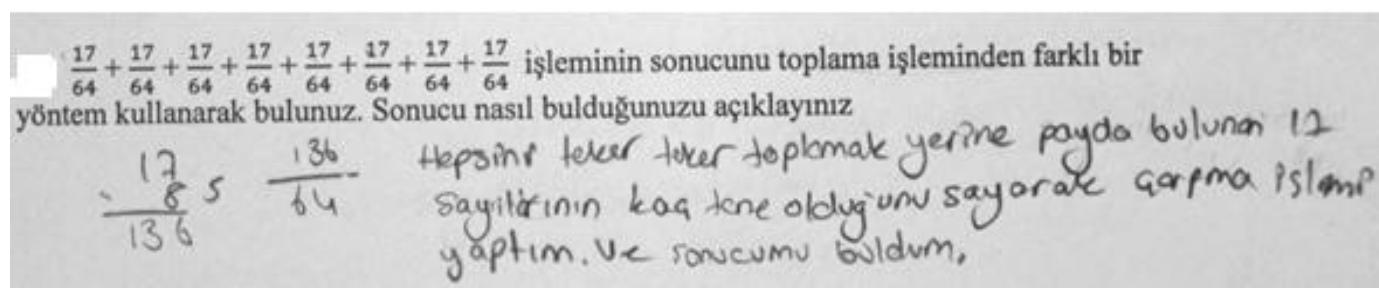

9. soruyu kural temelli çözen 022 kodlu öğrencinin verilen sayıları tek tek topladığı görülmektedir. 022 kodlu öğrencinin cevabı aşağıdaki gibidir. 
Şekil 20. 022 Kodlu Öğrencinin Cevab1

$\frac{17}{64}+\frac{17}{64}+\frac{17}{64}+\frac{17}{64}+\frac{17}{64}+\frac{17}{64}+\frac{17}{64}+\frac{17}{64}$ işleminin sonucunu toplama işleminden farklı bir yöntem kullanarak bulunuz. Sonucu nasıl bulduğunuzu açıklayınız

$$
\frac{17}{64}+\frac{17}{64}+\frac{17}{64}+\frac{17}{64}+\frac{17}{64}+\frac{17}{64}+\frac{17}{64}+\frac{17}{64}=\frac{136}{64}
$$

3. soruda öğrencilerden bir sayının, 1'den küçük rasyonel bir sayıyla çarpıldığında sayının küçüldüğünü anlaması beklenmektedir. Bu soruda ayrıca öğrencinin 5/8 sayısının yarımdan fazla olduğunu yorumlaması ve çarpma işlemi üzerindeki etkisini anlaması beklenmektedir. Tablo 5 incelendiğinde öğrencilerin çok azının bu soruya doğru cevap verdiği görülmektedir. Doğru cevap veren öğrencilerden birisi hariç diğerleri sayı duyusu bileşenlerini kullanmışlardır. 3. soruda sayı duyusu bileşeni kullanan 023 kodlu ve 03 kodlu öğrencilerin cevapları aşağıdaki gibidir.

Şekil 21.023 Kodlu Öğrencinin Cevabı

3) $6464 \times \frac{5}{8}$ işleminin sonycu 3232 'den büyük müdür, yoksa küçük müdür? Neden?

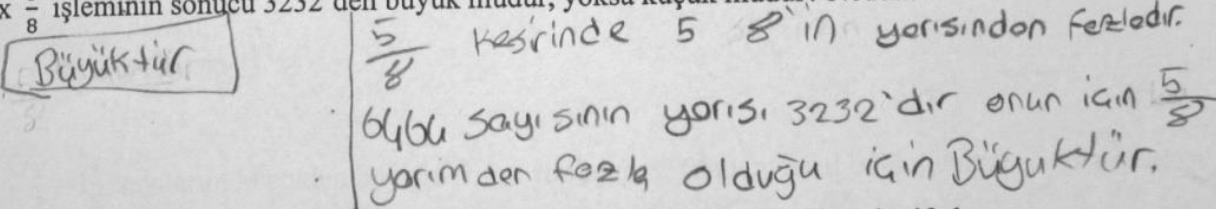

Şekil 22. 03 Kodlu Öğrencinin Cevab1

3) $6464 \times \frac{5}{8}$ işleminin sonucu 3232 'den büyük müdür, yoksa küçük müdür? Neden?

$$
\text { Buyvitior, } \frac{5}{8} \text { soyisi yorimdon farlodic }
$$

027 kodlu öğrenci cevap olarak "büyüktür" demesine rağmen açıklaması yetersiz olduğu için cevabı doğru olarak kabul edilmemiştir. Öğrencinin çarpma işleminin sonucunun çarpanlardan her zaman büyük olacağı yanılgısına sahip olduğu görülmektedir. 027 kodlu öğrencinin cevabı aşağıdaki gibidir.

Şekil 23. 027 Kodlu Öğrencinin Cevabı

3) $6464 \times \frac{5}{8}$ işleminin sonucu 3232 'den büyük müdür, yoksa küçük müdür? Neden?

$$
\text { Büyültür cünki aarpi var }
$$

Öğrencilerin genellikle rasyonel sayılarda çarpma işleminin sonucunu tahmin ederken toplama ve çıkarma işlemlerinden gelen kural temelli bir alışkanlıkla payda 
eşitledikleri ve yanlış cevaba ulaştıkları görülmektedir. 020 kodlu öğrencinin de benzer hatayı yaptığı görülmektedir. 020 kodlu öğrencinin cevabı aşağıdadır.

Şekil 24. 020 Kodlu Öğrencinin Cevabı

3) $6464 \times \frac{5}{8}$ işleminin sonucu, 3232'den büyük müdür, yoksa küçük müdür? Neden? Paydalari esitterim. $\frac{6464}{1} \times \frac{5}{8}=\frac{51712}{8} \times \frac{5}{8} \frac{25850}{8}$

031 kodlu öğrencinin rasyonel sayıların bir sayıyla çarpıldığında nasıl etki ettiğini bilmediği görülmektedir. Bununla ilgili 031 kodlu ve 019 kodlu öğrencilerin cevapları aşağıdadır.

Şekil 25. 031 Kodlu Öğrencinin Cevabı

3) $6464 \times \frac{5}{8}$ işleminin sonucu 3232 'den büyük müdür, yoksa küçük müdür? Neden? Evet büyüktïr. Günkü sayilar 8282 den büyüuktür.

Şekil 26. 019 Kodlu Öğrencinin Cevabı

3) $6464 \times \frac{5}{8}$ işleminin sonucu 3232 'den büyük müdür, yoksa küçük müdür? Neden?

$$
\begin{aligned}
& \text { Bence büyüktür aünkü islemde zaten } 3232 \text { den büyük } \\
& \text { bir sayi vor. }
\end{aligned}
$$

Bazı öğrencilerin rasyonel sayılarda çarpma işleminin nasıl yapıldığııı bilmedikleri için kural temelli yöntemle doğru cevabı bulamadıkları görülmektedir. 013 kodlu ve 016 kodlu öğrencilerin cevapları aşağıdadır.

Şekil 27. 013 Kodlu Öğrencinin Cevabı

3) $6464 \times \frac{5}{8}$ işleminin sonucu 3232 'den büyük müdür, yoksa küçük müdür? Neden?

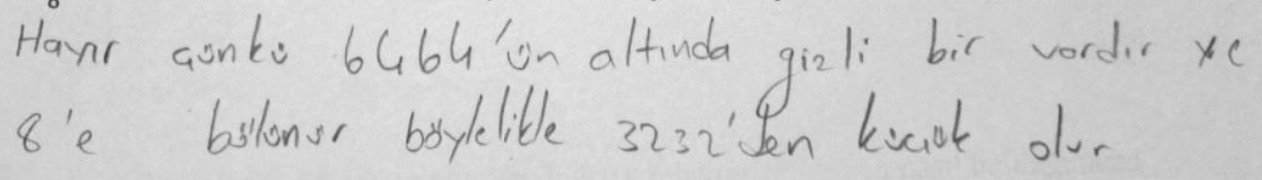

Şekil 28.016 Kodlu Öğrencinin Cevabı

3) $6464 \times \frac{5}{8}$ işleminin sonucu 3232'den büyük müdür, yoksa küçük müdür? Neden? Corpma istani bólme istanindon bu ùyüztur 
4. soruda öğrencilerden bölme işleminin etkisini anlayarak birinci ve ikinci işlemin aynı olduğunu anlaması beklenmektedir. Tablo 5 incelendiğinde öğrencilerin çok azının bu soruya doğru cevap verdikleri görülmektedir. Doğru cevap veren öğrencilerden sadece birinin sayı duyusu bileşenlerini kullandığı görülmektedir. 4. soruyu kural temelli çözen 019 kodlu ve 09 kodlu öğrencilerin cevapları aşağıda sunulmuştur.

Şekil 29. 019 Kodlu Öğrencinin Cevabı

4) "5628 x 2 işleminin sonucu,5628 : $\frac{1}{2}$ işleminin sonucundan büyüktür." Sizce bu ifade doğru mudur? Açıklayınız.

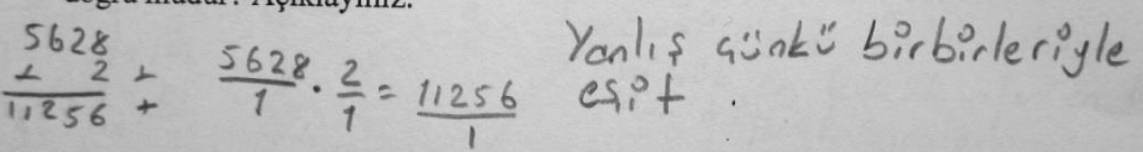

Şekil. 30. 09 Kodlu Öğrencinin Cevabı

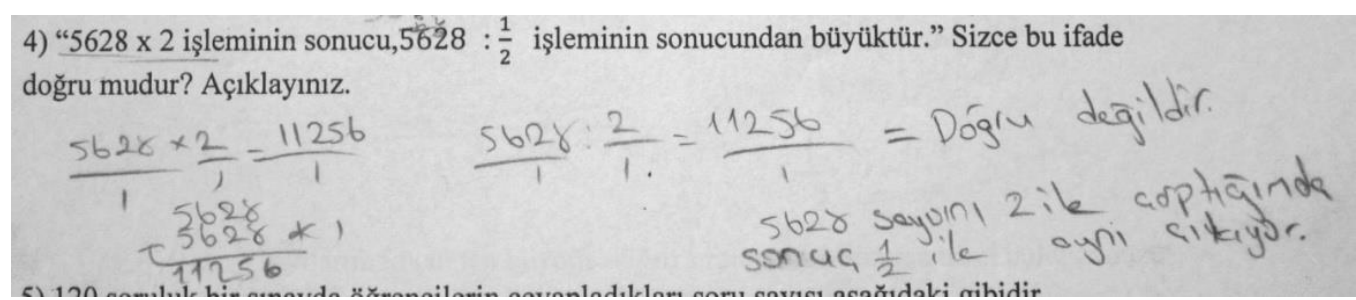

Bazı öğrencilerin rasyonel sayıların anlamını bilmedikleri, sadece çarpma ve bölme işlemlerine odaklandıkları görülmektedir. Bu konuyla ilgili 027 kodlu, 024 kodlu ve 032 kodlu öğrencilerin cevapları aşağıdadır.

Şekil 31. 027 Kodlu Öğrencinin Cevabı

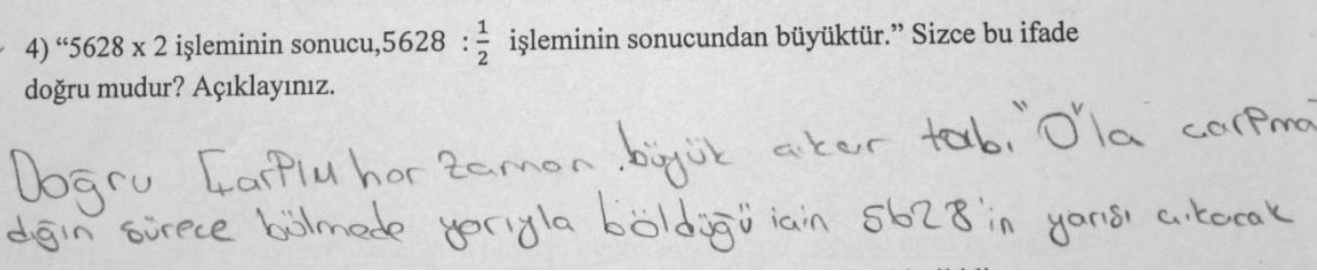

Şekil 32. 024 Kodlu Öğrencinin Cevabı

4) “5628 x 2 işleminin sonucu, $5628: \frac{1}{2}$ işleminin sonucundan büyüktür." Sizce bu ifade

doğru mudur? Açıklayınız.

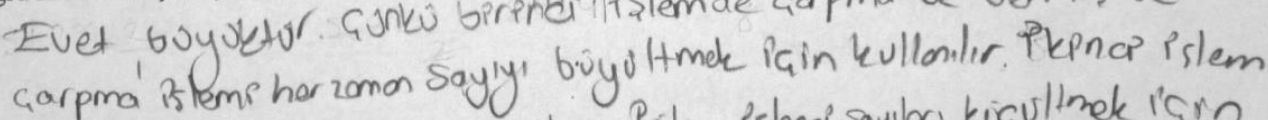

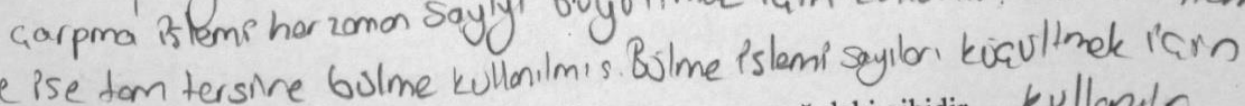
de ise tam tersine bulme kullanilmis. bulme islemi sayilar kuqu kullonin 
Şekil 33. 032 Kodlu Öğrencinin Cevabı

4) "5628 x 2 işleminin sonucu, $5628: \frac{1}{2}$ işleminin sonucundan büyüktür." Sizce bu ifade doğru mudur? Açıklayınız.

Hoyir yonlis cüpki $5628 \times 2$ islemi corpiligo $5628: \frac{1}{2}$ bölinúgo

Bazı öğrencilerin ise rasyonel sayının 1/2 ile bölünmesi işlemini, rasyonel sayının 2 ile bölünmesi işlemi ile eşdeğer tuttukları görülmektedir. 031 kodlu ve 015 kodlu öğrencilerin cevapları aşağıdadır.

Şekil 34. 031 Kodlu Öğrencinin Cevabı

4) "5628 x 2 işleminin sonucu,5628 : $\frac{1}{2}$ işleminin sonucundan büyüktür." Sizce bu ifade doğru mudur? Açıklayınız.

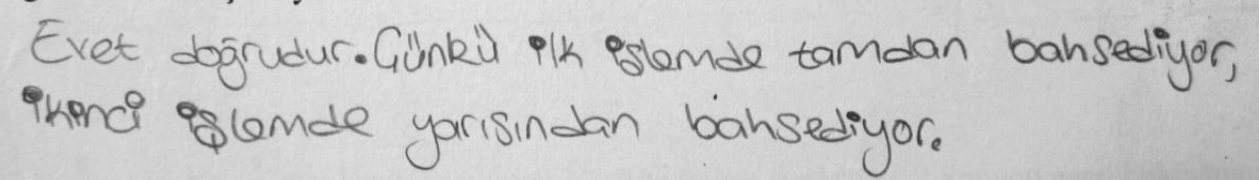

Şekil 35. 015 Kodlu Öğrencinin Cevabı

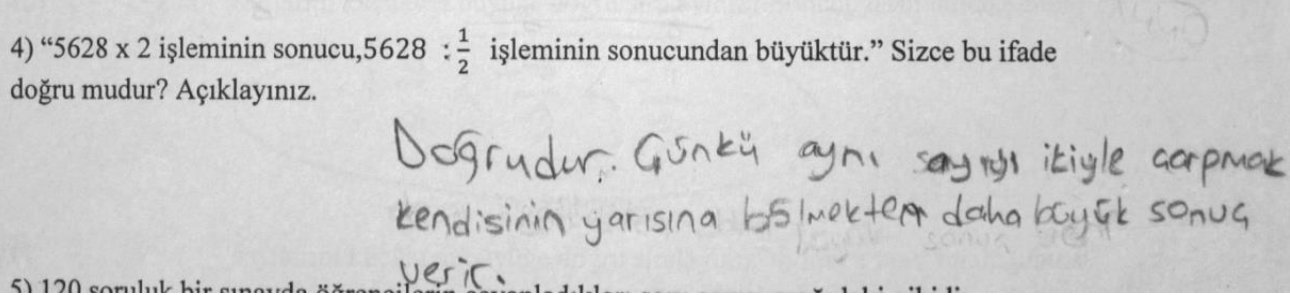

Zihinsel / esnek hesaplama sayı duyusu bileşeninin analizi. Sayı duyusu bileşenlerinden zihinsel / esnek hesaplamaya yönelik başarı testinde 5., 6., 7. ve 14.sorular sorulmuş ve analizleri Tablo 6' da sunulmuştur.

Tablo 6

Zihinsel / Esnek Hesaplama Sayı Duyusu Bileşeni Kullanımının Sorulara Göre Dağılımı

\begin{tabular}{lllllll}
\hline & Soru No & 5 & 6 & 7 & 14 & Toplam \\
\hline \multirow{2}{*}{ Doğru } & Sayı Duyusu & 5 & 2 & 0 & 1 & 8 \\
\cline { 2 - 7 } & Kural Temelli & 4 & 11 & 19 & 6 & 40 \\
\hline Yanlış & & 13 & 11 & 8 & 8 & 40 \\
\hline Boş & & 16 & 15 & 11 & 23 & 65
\end{tabular}

Tablo 6 incelendiğinde; 5. soruya doğru cevap veren öğrencilerin ancak yarısının sayı duyusu bileşeni kullandığı, diğer üç soruyu doğru cevaplayan öğrencilerin büyük bir kısmının ise kural temelli yöntemler kullandığı görülmektedir. 
5. soruda öğrencilerden çözülen soru sayılarının yaklaşık değerini hesaplamaları beklenmektedir. Tablo 6 incelendiğinde öğrencilerin yarısından daha azının soruyu doğru cevapladıkları görülmektedir. Soruyu doğru cevaplayan öğrencilerin yarısının kural temelli yöntemleri diğer yarısının ise sayı duyusu bileşenlerini kullandıkları görülmektedir. Öğrencilerin 5. soruda hesaplama yapmak yerine sadece verilen kesirlerin yarıma veya tama ne kadar yakın olduklarını dikkate alarak sıralama yaptıkları görülmektedir. Bu duruma örnek olarak 06 ve 08 kodlu öğrencilerin cevapları aşağıdadır.

Şekil 36. 06 Kodlu Öğrencinin Cevabı

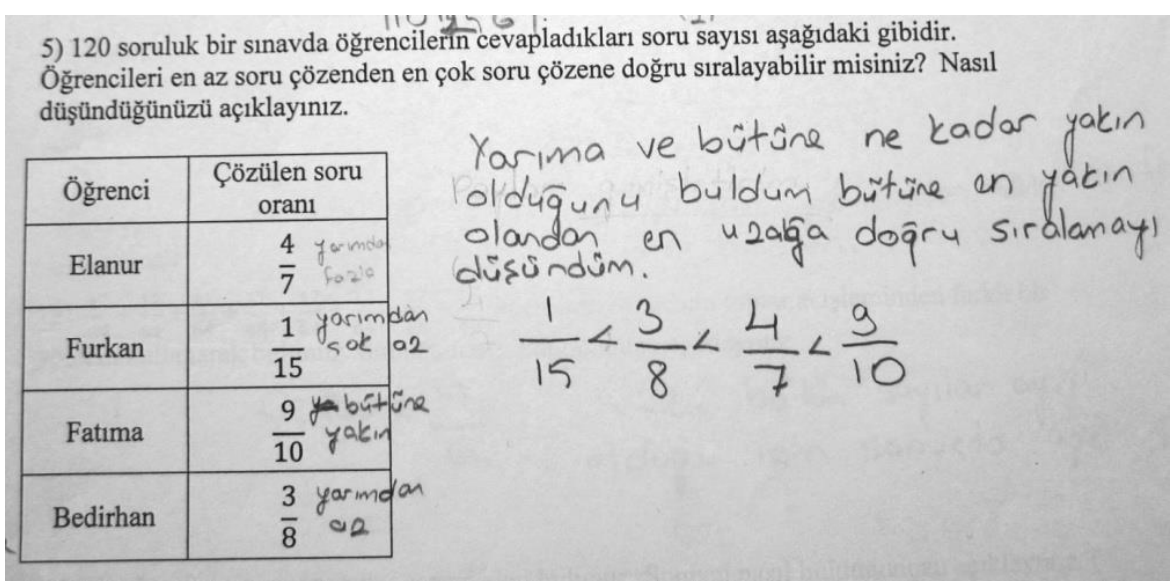

Şekil 37. 08 Kodlu Öğrencinin Cevabı

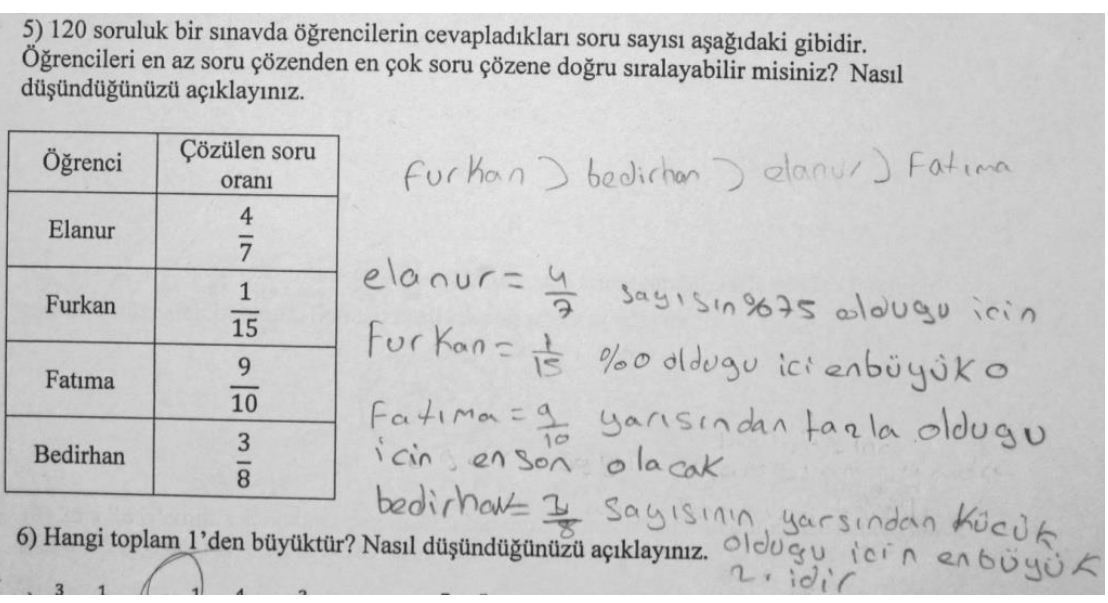

Bazı öğrencilerin ise kural temelli çözüm yaptıkları görülmektedir. Buna örnek olarak 024 kodlu öğrencinin cevabı aşağıdadır. 
Şekil 38. 024 Kodlu Öğrencinin Cevabı

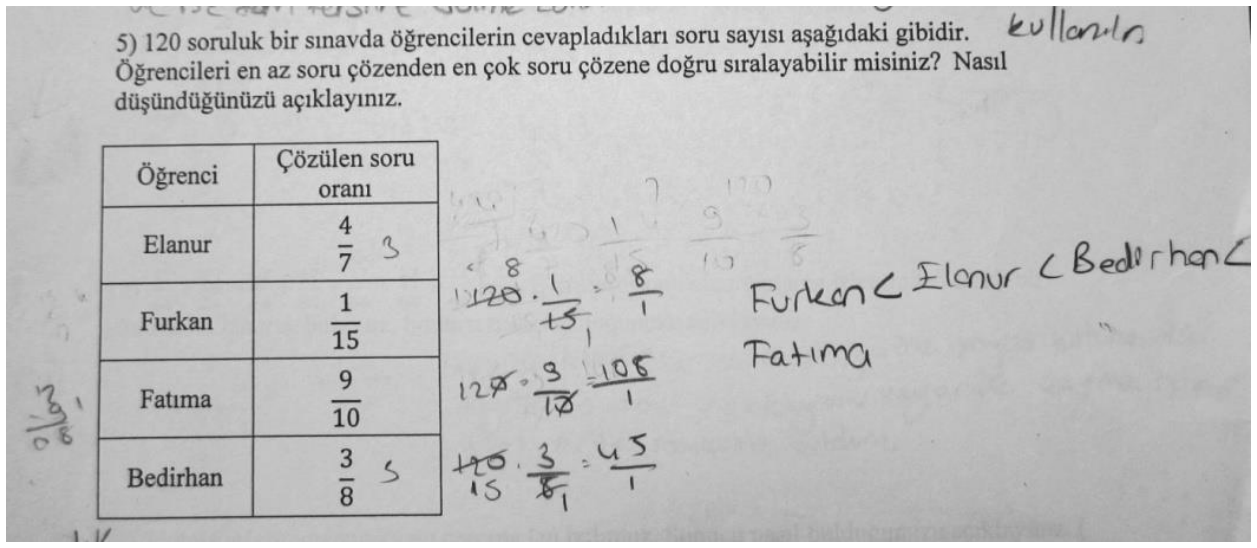

6. soruda öğrencilerden verilen kesirlerin yaklaşık değerlerini tahmin ederek işlem yapması beklenmektedir. 6. soruda hem sayı duyusu hem de kural temelli çözüm yapan 018 kodlu öğrencinin cevabı aşağıdadır.

Şekil 39. 018 Kodlu Öğrencinin Cevabı

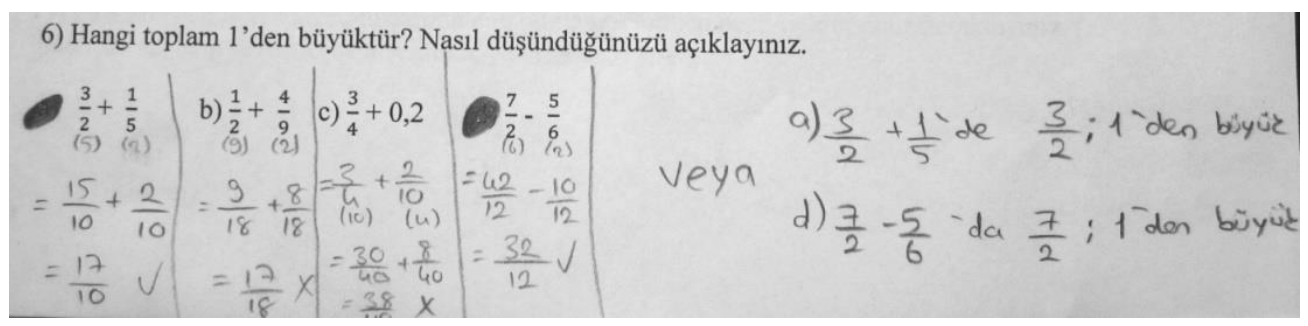

Bazı öğrencilerin 6. soruyu kural temelli yöntemle cevapladıkları görülmektedir. 6. Soruyu kural temelli yöntemle çözen 015 kodlu öğrencinin cevabı aşağıdadır.

Şekil 40. 015 Kodlu Öğrencinin Cevab1

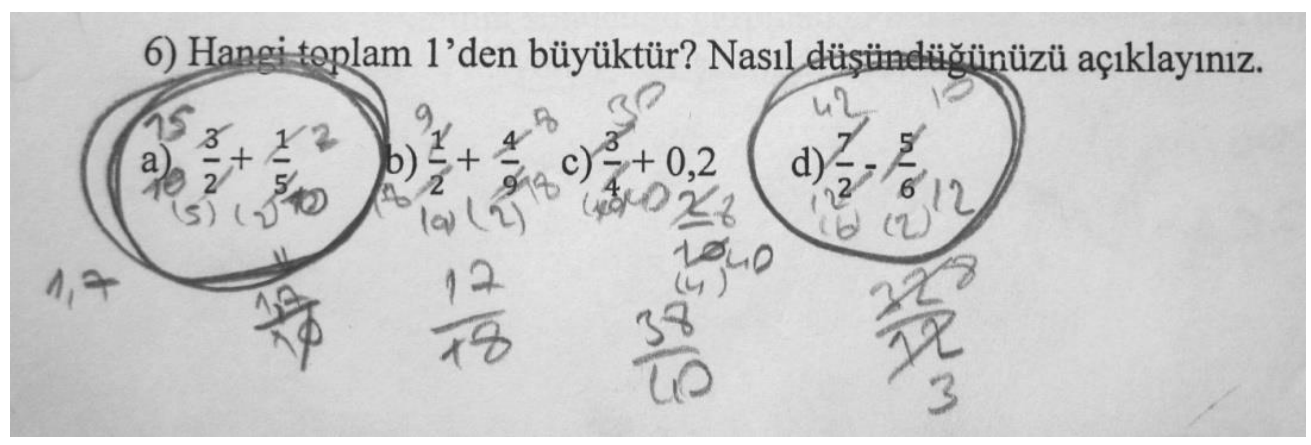

7. soruda öğrencilerin $2 / 5$ kesrinin yaklaşık değerini hesaplayarak işlemin sonucunu yaklaşık olarak tahmin etmeleri beklenmektedir. 7. soruya öğrencilerin yarısı doğru cevap vermiştir. Doğru cevap verenler içerisinden sayı duyusu bileşenini kullanan olmamıştır. 7. soruyu kural temelli çözen 07 kodlu öğrencinin cevabı aşağıdadır. 
Şekil 41. 07 Kodlu Öğrencinin Cevab1

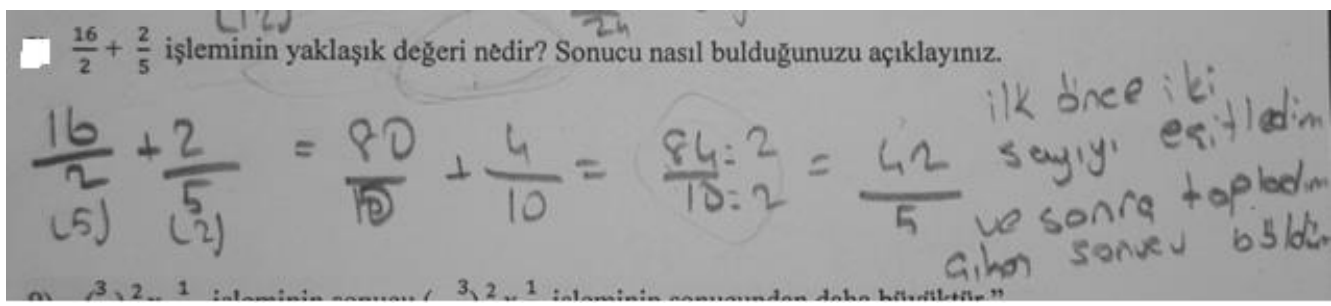

14. soruda öğrencilerden 1 tam $1 / 2$ kesrini yorumlamaları, çarpma işlemi yapmadan 84 ile 168 sayılarını toplamaları beklenmektedir. 14. soruya öğrencilerin çok azı doğru cevap vermiştir. Doğru cevap veren öğrencilerden sadece biri sayı duyusu bileşenini kullanmıştır. 14. Soruda sayı duyusu bileşeni kullanan 018 kodlu öğrencinin cevabı aşağıdadır.

Şekil 42. 018 Kodlu Öğrencinin Cevabı

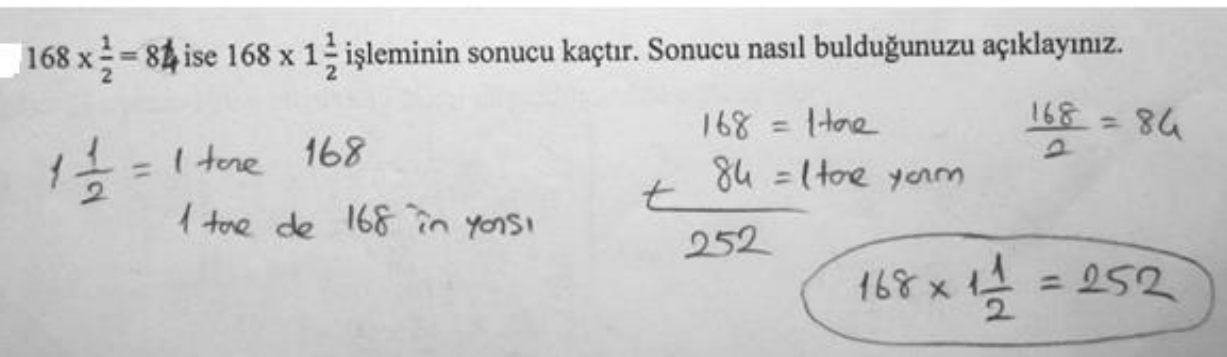

Bazı öğrencilerin ise 14. soruyu kural temelli yöntemlerle cevapladıkları görülmektedir. Kural temelli çözüm yapan 09 kodlu öğrencinin cevabı aşağıdadır.

Şekil 43. 09 Kodlu Öğrencinin Cevabı

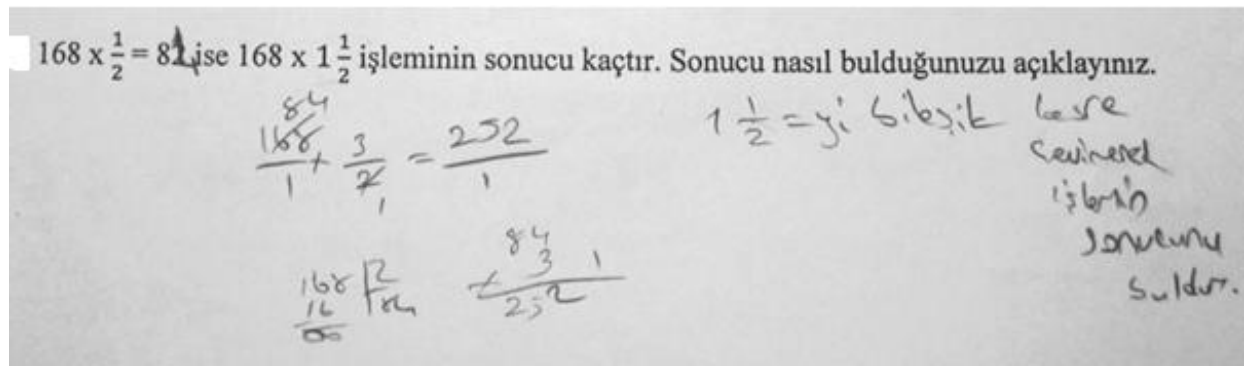

\section{Sonuç ve Tartışma}

Bu çalışmada 38 yedinci sınıf öğrencisinin rasyonel sayılara yönelik sayı duyusu kullanımı cinsiyet, okul öncesi eğitim alma ve sayı duyusu bileşenleri değişkenlerine göre belirlenmeye çalışılmıştır.

Araştırmaya katılan öğrencilerin sayı duyusu kullanımları cinsiyet değişkeni açısından incelendiğinde kız öğrencilerin erkek öğrencilerden daha başarılı oldukları görülmektedir. Bu konuda alan yazında yapılan çalışmalarda farklı sonuçlar bulunduğu görülmektedir. Yapıcı (2013) tarafından yapılan çalışmada sayı duyusu kullanımında erkek öğrenciler lehine anlamlı bir farklılık olduğunu tespit etmiştir. Er \& Dinç-Artut 
(2017), Harç (2010) ve Kayhan-Altay (2010) tarafından yapılan çalışmalarda ise cinsiyetin sayı duyusu bileşenlerini kullanmada etkili olmadığı tespit edilmiştir.

Araştırmaya katılan öğrencilerin sayı duyusu kullanımları okul öncesi eğitim alma durumu açısından incelendiğinde okul öncesi eğitim alan öğrencilerin almayanlardan daha başarılı oldukları görülmektedir. Matematik eğitiminin en önemli amaçlarından biri olan çocuklara sayı duyusunun kazandırılması, okul öncesi eğitimde üzerinde en çok durulan konulardandır. Jordan, Kaplan, Olah \& Locuniak (2006), sayı hissinin okul öncesi dönemde gelişmeye başladığını belirterek okul öncesi çocuklarının sahip olduğu matematiksel becerilerden yola çıkarak beş ana alan tespit etmiş ve bu alanlara ait sayı hissi bileşenlerini "sayma, sayı bilgisi, sayı dönüşümü, tahmin ve sayı örüntüleri” olarak belirlemiştir. Şengül \& Gülbağcı-Dede (2013) tarafından okul öncesi öğrencilerine ve daha üst sınıf düzeyindeki öğrencilerine uygulanan sayı duyusu testlerinin birçok ortak görev içerdiği ifade edilmektedir. Taşkın (2011), sayı duyusunun erken gelişiminin ilerideki matematik eğitiminin temeli olduğunu ve eğer çocuk bu konuda sorun yaşarsa muhtemelen daha sonra da öğrenme güçlügü ile karşılaşacağını ifade etmektedir. Ancak okul öncesi eğitimin sayı duyusu kazanımına etkisinin tam olarak belirlenebilmesi için bu konuda daha çok araştırmaya ihtiyaç olduğu düşünülmektedir.

Öğrencilerin sayı duyusu kullanımı sayı duyusu bileşenleri açısından incelendiğinde öğrencilerin işlemlerin sayılar üzerindeki etkisi bileşeninde daha başarılı oldukları görülmektedir. Öğrencilerin bu bileşende başarılı olmaları başarı testindeki ilgili soruların zorluk düzeyinden kaynaklanmış olabilir. Bu sonucun İymen \& DuatepePaksu (2015) tarafından yapılan çalışmanın sayı duyusu kullanımı ile sorunun yapısı arasında ilişki olduğu sonucunu desteklediği söylenebilir. Sayı duyusu bileşeninin en az kullanıldığı alan ise zihinsel / esnek hesaplama olmuştur. Nitekim Yapıcı (2013) da yaptığı çalışma sonucunda öğrencilerin pratik düşünmede, yaklaşık değer bulmada ya da tahminde bulunmada yetersiz kaldıklarını tespit etmiştir.

Öğrencilerin kural temelli yöntemlerde ise sayıların eşdeğer temsillerinin yazılmasında ve zihinsel esnek hesaplamada daha başarılı oldukları görülmektedir.

Elde edilen sonuçlara göre öğrencilerin başarı testindeki soruları çözmek için daha çok kural temelli çözüm yaptıkları, sayı duyusu bileşenlerini çok fazla kullanmadıkları görülmektedir. Bu sonuç sayı duyusuyla ilgili daha önce yapılan çalışmaların sonuçlarıyla benzerlik göstermektedir (Bayram, 2013; Er \& Dinç-Artut, 2017; İymen \& Duatepe-Paksu, 2015; Kayhan-Altay, 2010; Şengül \& Gülbağc1, 2013; Yapıc1, 2013). Öğrencilerin soruların çözümünde sayı duyusu bileşenlerini kullanmayıp kural temelli çözüm yapmalarına rağmen bazı sorularda rasyonel sayılar ve diğer konulardaki eksikliklerinden dolayı doğru sonuca ulaşamadıkları görülmektedir. Nitekim İymen \& Duatepe-Paksu (2015) da yaptıkları çalışma sonucunda öğrencilerin üslü sayılarda sayı duyusu kullanmamalarına temelde tam sayılar ve rasyonel sayılardaki eksikliklerin neden olduğunu belirtmişlerdir.

Öğrencilerin sayıları ve işlemleri yorumlayıp tahmin etme, muhakeme yapma ve pratik düşünme gibi yolları kullanmayı tercih etmedikleri görülmektedir. Öğrenciler soruların çözümüne öğrendikleri uzun çözüm yolları ile kural temelli yaklaşmaktadırlar. Birçok öğrenci ise kuralları tam öğrenmediği için veya unuttuğu için kural temelli çözümlerde hata yapmaktadırlar. Kural temelli öğrenilen bilgiler uzun zaman diliminden sonra unutulabilmektedir. Fakat sayı duyusu bileşenlerinin unutulması zor 
olacağı için öğrencilerin hayatlarında her zaman kullanabilecekleri bir araç olabilmektedir.

Öğrencilerin genel olarak rasyonel sayılarda çarpma işlemi yaparken payda eşitledikleri, iki rasyonel sayı arasındaki sayıyı yazmaları istendiğinde pay ve payda arasındaki sayıları yazdıkları, verilen uzunluğa göre sayıları sayı doğrusuna sıralamaları istendiğinde öğrencilerin verilen uzunluğu dikkate almadıkları, verilen sayıları sıralamaları istendiğinde sayıların eksi işaretlerini dikkate almadıkları tespit edilmiştir. Bazı öğrencilerin bir kesrin yaklaşık değerini ya da kesirlerin yarıma veya tama ne kadar yakın olduklarını tahmin edemedikleri görülmektedir. Ayrıca öğrencilerin kesirlerin yaklaşık değerlerini kullanarak bir tam sayının istenilen kesir kadarını bulamadıkları tespit edilmiştir. Bazı öğrencilerin rasyonel sayıların çarpma ve bölme işlemlerindeki etkisinin, tam sayılardaki gibi olduğunu düşündükleri tespit edilmiştir. $\mathrm{Bu}$ öğrenciler çarpma işleminin her zaman sayıyı büyüttüğünü, bölme işleminin ise her zaman sayıyı küçülttüğünü düşünmektedirler. Nitekim İymen \& Duatepe Paksu (2015) da yaptıkları çalışma sonucunda işlemlerin etkilerini anlama konusunda öğrencilerin yetersiz olduklarını tespit etmişlerdir. Benzer şekilde Harç (2010) da yaptığı çalışma sonucunda öğrencilerin "Çarpma işlemi büyütür, bölme işlemi küçültür" genellemelerini yaptıklarını tespit etmiştir. $\mathrm{Bu}$ durum "aşırı genelleme" olarak adlandırılan bir kavram yanılgısından kaynaklanmaktadır. Bu bağlamda öğrencilerin sayı hissinin sahip oldukları kavram yanılgıları ile de yakından ilgili olduğu söylenebilir. Nitekim alan yazında sayı duyusunun yeterli düzeyde oluşmamasının bu tür yanılgılara yol açabileceği çeşitli araştırmalarda dile getirilmektedir (Bayram, 2013; Şengül, 2013). Diğer yandan sayı duyusu gelişiminin işlemsel ve kavramsal bilgiyi birlikte gerektirdiği söylenebilir. Sayı duyusu bileşenlerinden de anlaşılacağı üzere sayı duyusu, hem sayılarla doğru işlem yapabilmeyi hem de işlem yapılan sayıların anlamını kavramayı gerektirmektedir. Nitekim McIntosh ve diğerleri (1992) de sayı duyusunu; sayılar, işlemler ve sayılarla işlemlerin uygulamaları şeklinde kavramsal ve işlemsel bilgi bağlamında ele almıştır.

Bayram (2013) öğrencilerin sayı duyusu kullanma becerilerinin farklı sorular sorularak, farklı etkinlikler uygulanarak geliştirilebileceğini ifade etmiştir. Öğrencilere sayı duyusu bileşenlerini kullanma yöntemlerini en iyi aktaracak kişiler ise öğretmenlerdir. Öğretmenlerin bunu yapabilmesi için sayı duyusu kullanımının öneminin farkına varması ve sayı duyusu bileşenleri hakkında bilgi sahibi olması gerekmektedir. Sayı duyusu bileşenlerini kullanan öğretmenler bildiklerini öğrencilerine daha iyi aktarabilecekler, ders içinde sayı duyusu etkinliklerine daha fazla yer verebileceklerdir. Fakat yapılan bazı araştırmalarda öğretmenlerin sayı duyularının yeterli düzeyde olmadığı ortaya çıkmıştır. Şengül \& Gülbağc1-Dede (2014) tarafından yapılan çalışmanın sonucunda öğretmenlerin problem çözümlerinde sayı duyusu stratejilerini kullanma konusunda iyi seviyede olmasalar da orta düzeyde oldukları tespit edilmiştir. Şengül (2013) tarafından yapılan araştırma sonucunda sınıf öğretmeni adaylarının sayı duyularının oldukça düşük düzeyde olduğu tespit edilmiştir.

\section{Öneriler}

Araştırmadan elde edilen bulgular ışı ğında aşağıdaki öneriler geliştirilmiştir.

1) Sınıf içi problem çözme etkinliklerinde öğrencilerin problemleri çözmeden önce sonucu yaklaşık olarak tahmin etmeleri istenebilir. 
2) Öğrencilerin işlemleri yapmadan önce sonucu yaklaşık olarak tahmin etmeleri istenebilir.

3) Sayı duyusu bileşenlerinin kullanımına cinsiyetin etkisi olup olmadığına ilişkin daha fazla araştırma yapılabilir.

4) Eğitim fakültelerinde okutulan Matematik Öğretimi ve Özel Öğretim Yöntemleri gibi derslerde sayı duyusu bileşenleri ve kullanımı üzerine uygulamalı çalışmalar yapılabilir. 


\section{Summary}

Purpose and Significance: One of the methods we need in daily life is to make an instant judgment and arrive at a judgment. When estimating the height of a person, a reference point is usually taken to try to guess. Or, when a product value is calculated, it is tried to be valued by looking at a product with the same value. It is expected that in daily life individuals will be able to give estimated answers such as "half full, half a little more than half, and a little less than three quarters" in the question "how much water is there in a glass?" In order to make a good guess, it is necessary to know the numbers and know what they mean. Suppose a grape producer has 98 sack grapes. Let's say that each grape sack has an average of $56 \mathrm{~kg}$. In this case, the farmer is expected to roll 98 sacks to 100 sacks using the sense of number and say "56 x 100 produce about $5600 \mathrm{~kg}$ raisins". The way in which pupils use the sense of number can be achieved by learning the strategy of number sense from elementary school. When the literature is examined in the literature, it is seen that studies on different number groups about number sense are made. There was no study of the use of the sense of numbers for rational numbers. In this context, it is thought that this work will contribute to the field of mathematics education in filling this gap in the field. Within the scope of the study, the following subproblems were searched. How is the distribution of the sense of numbers used by 7 th graders in relation to rational numbers by gender? How is the distribution of the sense of numbers used by 7th graders on rational numbers according to pre-school education? How is the distribution of the sense of numbers used by 7 th graders in terms of rational numbers?

Methods: This study is a qualitative research and the state study model is used from the descriptive research methods. The study group of the study is composed of 38 middle school 7th grade students who are studying in a public school in Manisa province in the academic year 2016-2017. There are 19 female and 19 male students in the study group. The 29 students had pre-school education and 9 students stated that they did not have pre-school education. A number sense of achievement test was prepared by the researchers, taking into consideration the achievement tests prepared for the field of numbers in the field and the achievements of the rational numbers in the 7 th grade curriculum of the MEB (2013). The number sense achievement test consists of 14 questions in the context of the four number sense components. The identified number sense components are as follows: 1) Understanding Equivalent Representations of Numbers 2) Understanding the Meaning and the Size of the Numbers 3) Impact of Operations on Numbers 4) Mental / Flexible Calculation. Content analysis was used during the analysis of the data. The data obtained from the application were tabulated. The answers given by the students to the questions were classified into 4 categories as "rule based, number sense, wrong and empty".

Results: When the number sense of students is examined in terms of gender, it is seen that female students are more successful than male students. In this regard, it is seen that there are different results in the field studies. When the use of students' sense of numbers is examined in terms of pre-school education, it is seen that pre-school students are more successful than non-students. When the use of the students' sense of numbers 
is examined in terms of the components of the sense of numbers, it is seen that the students are more successful in the components of the effects on the numbers. The success of the students in this component may be due to the difficulty level of the relevant questions in the success test. It is seen that students are more successful in rulebased methods when writing equivalent representations of numbers and in mental flexible calculations. When students are asked to write numerals between two rational numbers when they are asked to write numerical numbers between two rational numbers, it is determined that students do not take into account the length given by the students when they are asked to order numerical numbers according to the given length. It has been found that some students think that the effect of rational numbers on the multiplication and division processes is like the exact numbers. These students think that the multiplication process always increases the number and the division process always reduces the number. It is seen that some students can not estimate the approximate value of a sequence or how close the fractions are to the fraction or the tama. It was also found that the students could not find the desired fraction of an exact number using the approximate values of the fractions.

Discussion and Conclusions: According to the results obtained, it is seen that the students have more rule-based solutions to solve the questions in the success test, and they do not use the number sense components too much. This result is similar to the results of previous studies on number sense. Although the students do not use the number sense components in the solution of the questions and make rule-based solutions, it is seen that some questions do not reach the right result due to rational numbers and other deficiencies. It is seen that students do not prefer to use ways such as interpreting and predicting numbers, reasoning and practical thinking. The students are approaching the rule-based approach with long solutions they learn to solve the questions. Many students make mistakes in rule-based solutions because they do not learn rules or forget them. Rule-based information can be forgotten after a long period of time. But it is a tool that students can always use in their lives because it is difficult to forget the sense of number components. Teachers are the ones who best convey the methods of using the number sense components to the students. In order for teachers to be able to do this, they must be aware of the importance of the use of the sense of number and knowledge of the components of the sense of number. Teachers who use number sense components will be able to transfer their knowledge to their students better, and they will be able to give more number sense activities in the lesson. The following can be suggested for future work.

1) In classroom problem solving activities, students may be asked to approximate the result before solving the problems.

2) Students may be asked to make an approximate estimate of the outcome before proceeding.

3) Further research can be done to determine whether gender impacts on the use of number sense components.

4) Practical studies on number sense components and their use can be done in courses such as mathematics education and special teaching methods taught in education faculties. 


\section{Kaynakça}

Baykul, Y. (2014). Ortaokulda matematik öğretimi. Ankara: Pegem Akademi

Bayram, G. (2013). 8. sınıf ögrencilerinin üslü ifadelere ilişkin sayı duyuları ve başarıları arasındaki ilişki (Yüksek lisans tezi). Pamukkale Üniversitesi Eğitim Bilimleri Enstitüsü, Denizli.

Büyüköztürk, Ş., Çakmak, E. K., Akgün, Ö. E., Karadeniz, Ş., \& Demirel, F. (2016). Bilimsel araştırma yöntemleri. Ankara: Pegem Akademi

Er, Z., \& Dinç Artut, P. (2017). Sekizinci sınıf öğrencilerinin doğal sayı, ondalıklı sayı, kesirler ve yüzde konularında kullandıkları sayı duyusu stratejilerinin incelenmesi. International Journal of Social Sciences and Education Research, 3(1), 218-229

Greeno, J. G. (1991). Number sense as situated knowing in a conceptual domain source. Journal for Research in Mathematics Education, 22(3), 170-218.

Harç, S. (2010). 6. Sınıf öğrencilerinin sayı duygusu kavramı açısından mevcut durumlarının analizi (Yüksek lisans tezi). Marmara Üniversitesi, İstanbul.

İymen, E., \& Duatepe-Paksu, A. (2015). 8. Sınıf öğrencilerinin üslü ifadeler ile ilgili sayı duyularının sayı duyusu bileşenleri bakımından incelenmesi. Ĕ̈itim ve Bilim Dergisi, 40(177), 109-125.

Jordan, N., C., Kaplan, D., Nabors Olah, L., \& Locuniak, M. N. (2006). Number sense growth in kindergarten: A longitudinal investigation of children at risk for mathematics difficulties. Child Development, 77(1), 153-175.

Karasar, N. (2016). Bilimsel araştırma yöntemi: Kavramlar ilkeler teknikler. Ankara: Nobel Akademik Yayınc1lık.

Kayhan-Altay, M. (2010). İlköğretim ikinci kademe öğrencilerinin sayı duyularının sinıf düzeyine, cinsiyete ve sayı duyusu bileşenlerine göre incelenmesi (Doktora tezi). Hacettepe Üniversitesi, Ankara.

Kayhan-Altay, M., \& Umay, A. (2011). Sınıf öğretmeni adaylarının hesaplama becerileri ve sayı duyuları arasındaki ilişkinin incelenmesi. Education Sciences, 6(1), 1277-1283.

Miles, M. B., \& Huberman, A. M. (1994). Qualitative data analysis: an expanded sourcebook. (2nd Edition). Calif. : Sage Publications

Milli Eğitim Bakanlığı [MEB]. (2013). Matematik dersi öğretim programı. Ankara: MEB Basımevi.

Milli Eğitim Bakanlığı [MEB]. (2017). Matematik dersi öğretim programı. Ankara: MEB Basımevi.

Reys, R. E., \& Yang, D. C. (1998). Relationship between computational performance and number sense among sixth and eighth-grade students in Taiwan. Journal for Research in Mathematics Education, 29(2), 225-237.

Reys, R., Reys, B., McIntosh, A., Emanuelsson, G., Johansson, B., \& Yang, D. C. (1999). Assessing number sense of Students in Australia, Sweeden, Taiwan, andthe United States. School Science and Mathematics, 99(2), 61-70. 
Şengül, S. (2013). Sınıf öğretmeni adaylarının kullandıkları sayı duyusu stratejilerinin belirlenmesi. Kuram ve Uygulamada Ë̆itim Bilimleri, 13(3), 1951-1974.

Şengül, S., \& Gülbağcı Dede H. (2014). Matematik öğretmenlerinin sayı hissi problemlerini çözerken kullandıkları stratejiler. Turkish Journal of Computer and Mathematics Education, 1(5), 73-88.

Şengül, S., \& Gülbağcı H. (2013). 7. ve 8. Sınıf öğrencilerinin sayı hissi ile matematik öz yeterlikleri arasındaki ilişkinin incelenmesi. International Journal of Social Science, 4(6), 1049-1060.

Şengül, S., \& Gülbağcı H. (2013). Sayı hissi bileşenlerine ait sınıflandırmaların incelenmesi. International Journal of Social Science, 6(8), 645-664.

Taşkın, N. (2011). Küçük çocuklarda sayı kavramı. Berrin Akman (Ed.), Okul Öncesi Matematik Ë̆itimi içinde (s. 67-90). Ankara: Pegem Akademi

Ulusoy, Ç. A., \& Şahiner, Y. (2016). Sayı duyusuna yönelik öz yeterlik ölçeğinin geliştirilmesi. Kastamonu Ĕgitim Dergisi, 25(1), 17-32.

Yang, D. C., \& Tsai, Y. F. (2010). Promoting Sixth Graders' Number Sense and Learning Attitudes via Technology-based Environment. Educational Technology \& Society, 13(4), 112-125.

Yapıc1, A. (2013). 5.,6. ve 7. Sinıf öğrencilerinin yüzdeler konusunda sayı duyularının incelenmesi (Yüksek lisans tezi). Hacettepe Üniversitesi, Ankara. 